\title{
OSTRUHY JAKO DOKLADY PŘÍTOMNOSTI ELITY V 8. A 9. STOLETÍ $\mathrm{V}$ ČECHÁCH
}

\author{
NAĎA PROFANTOVÁ
}

\begin{abstract}
Abstrakt: Článek zveřejňuje poznatky o nových bronzových a železných ostruhách s háčky z Čech. Tím se zvýšil počet lokalit s nálezy bronzových ostruh na šest, celkový počet lokalit s ostruhami s háčky na 23 , resp. 24, zdokumentovali jsme nové typy či varianty. Ostruhy patř́ mezi důležité nálezy s relativní chronologickou citlivostí, zaměrujeme se na nejstarši skupiny s háčky a očky, vydělujeme několik importů včetně ostruh s ploténkami. Nově byly provedeny RFA analýzy několika bronzových kusů a jejich složení bylo porovnáno se složenim moravských kusư; v některých prípadech lze uvažovat i o cínování, postřibření či pozlacení (Mikulčice). Zároveň se podařilo zachytit technologické detaily jako vybrušování háčkủ (Sadská) či pokus pomocí pájky připevnit znovu odlomený háček (Mukov). Některé nálezy mimo hradiště ukazují nejspíše na průběh dálkových komunikací.
\end{abstract}

Klíčová slova: ostruhy - raný středověk - Čechy-Morava-karolinský import-RFA analýzy-cínování.

\section{Spurs as the Evidence of the Presence of Elites in Bohemia in the 8th and 9th Centuries}

\begin{abstract}
This article presents new information about bronze and iron spurs with hooks from Bohemia. The number of sites that have yielded bronze spurs thus rose to six, the total of sites with spurs with hooks being 23 or 24. New types and variants were documented. Spurs belong with important finds with relative chronological sensitivity; the research focused on the oldest groups with hooks and loops among which several imports were determined, including spurs with discs. RFA analyses of several bronze items were conducted and their composition was compared to that of spurs from Moravia. Some of the spurs were probably pewtered, silvered or gilded (Mikulčice, Skorkov). At the same time, technological details such as the sharpening of hooks (Sadská) and an attempt to reattach a broken hook using a soldering iron (Mukov) were noted. Some finds that do not come from hillforts probably indicate the course of long-distance routes.
\end{abstract}

Key words: spurs-early Middle Ages-Bohemia-Moravia-Carolingian import-RFA analyses-pewtering.

\section{1 Úvod}

Ostruhy patří mezi důležité nálezy s relativní chronologickou citlivostí. Pro dobu, kdy se v Čechách pohřbívalo žárově (konec 6. století až 2. čtvrtina až polovina 9. století), mají tyto nálezy ještě větší význam, nebot' jsou jedním z mála svědectví o př́itomnosti jezdců-bojovníků na té které lokalitě. Jejich kumulace pak stvrzuje značný význam některých lokalit, v Čechách např. Rubínu u Podbořan ( 8 či více ks) či Toušně, na Moravě nap̌r. Mikulčic či Brna-Líšně (souhrnně Profantová 1994; k Mikulčicím nověji Klanica 1995; Kavánová 1998, zvl. obr. 5). Tam, kde se vyskytují spolu s bronzovými kováními avarského kulturního okruhu (např. Dolánky-Rubín, Tismice, Sv. Jan pod Skalou apod.), ukazují odlišnou mocenskou konstelaci od vlastní Avárie, nebot' avarští jezdci poháněli koně bičem. Proto se v této rozsahem omezené práci budeme podrobněji věnovat starším typům ostruh a pouze $\mathrm{v}$ závěru stručně shrneme jejich význam $\mathrm{v}$ hrobech. To totiž umožní lépe demonstrovat sociální statutární význam ostruh v tehdejší společnosti.

Od souhrnu poznatků o ostruhách s háčky z Čech uplynulo více než 20 let (Profantová 1994). Novější nálezy byly publikovány jen z Toušně (Profantová-Špaček 2003) a též z Češova (Profantová 2012, obr. 2:8). Nedávno jsem nejdůležitější výsledky shrnula v souvislosti s dalšími nálezy související s jezdectvím (Profantová 2015), ovšem v souhrnu nebyl prostor pro detailní informace o poloze nálezů, detailní popis nálezů samých ani výsledky rentgenové fluorescenční analýzy (RFA), případně dalších analýz. Navíc se podařilo zdokumentovat další bronzové i železné nálezy. Chci je na tomto místě zveřejnit a analyzovat. Podařilo se mi díky mikrofotografiím a výsledkům RFA učinit některá nová zjištění či popsat nové technologické detaily jak na nových nálezech (Sekeřice/Osek, Mukov, Senohraby, Roštín na Moravě), tak v případě starého nálezu ze Sadské, okr. Nymburk (obr. 3b). 


\section{Soupis nových nálezů}

V následujícím přehledu nových nálezů postupujeme tak, že napřed uvedeme ostruhy technotypu I - bronzové, pak technotypu T II a III (železné).

Lokality jsou řazeny v těchto dvou kategoriích abecedně. Struktura jednotlivých položek je následující: pořadové číslo, lokalita a okres (v případě nálezu na hradišti ještě odkaz na literaturu), rok nálezu - je-li znám, slovní lokalizace a zaměření, slovní popis ostruhy, rozměry; také je uvedena hmotnost ostruhy, pokud tento údaj známe, a odkaz na obrázek. V případě bronzových ostruh je uvedeno, že proběhla analýza RFA, prŕípadně nejdůležitější výsledek. V některých případech je dodána poznámka o významném nálezu v okolí či o specifickém typu nálezu apod.

\section{A Bronzové kusy}

\section{Sobotka-Spyšova, okr. Jičín}

Nalezeno v roce 2011 s pomocí detektoru kovu, směr na Markvartice (nejbližší hájovna Spařence). Poloha ostruhy je zachycena na mapce. Zaměření: 50²6'37,361" N, 15¹1'29,528" E. Obr. 1.

Popis: Bronzová ostruha s dovnitř zahnutými háčky a vsazeným bodcem. Ramena jsou zdobena dvěma plochými vývalky a hustším rýhováním. Výzdoba sahá téměř do poloviny ramen. Ta jsou trojúhelníkovitého průřezu. Rameno se v místě umístění bodce rozšiřuje. Bodec je kruhového průřezu, zdoben dvěma vývalky, s největší pravděpodobností vsazený. Rozměry: rozpětí ramen $83 \mathrm{~mm}$, v. 79,2 $\mathrm{mm}$, z toho bodec $22 \mathrm{~mm}$. Obr. 4:2; 7c.

\section{Mukov, okr. Teplice}

Nalezeno na jaře 2011 s pomocí detektoru kovů v lese na kamenitém políčku nedaleko pramene, mezi Hradištany a Štepánovskou Horou (tedy pravěkými hradišti; ${ }^{1}$ srov. Čtverák-Lutovský-Slabina-Smejtek 2004, 309, 207/8: kultura knovízská a štítarský stupeň), kde se našly i nálezy z doby římské a jehlice z doby bronzové, nejspíš jde o cestu. Zaměření: 50³0'49" N, 1352'0.97" E. Obr. 2.

Popis: Litá bronzová ostruha s dovnitř zahnutými háčky s rameny trojúhelníkovitého průřezu. Jen jeden háček je odlomen. Na konci jednoho ramene jsou čtyři výrazné vývalky, ke svislé ose nasedají ve fázovém posunu, takže ve středu vzniká klikatka. Druhé rameno má zachovány jen tři vývalky bez fázového posunu. Na úzké hraně pod výzdobou jsou viditelné husté rýžky stopy po opracování ostruhy spíše než výzdoba. Bodec nejspíše připevněný zvlášt' má prohnutý krček, dva ozdobné vývalky a následně hráněný zužující se tvar. Rameno ostruhy má nad bodcem vyhlazenou plošku zdobenou dvěma šikmými rýžkami a dvěma vnějšími hlubšími rýhami ohraničujícími zdobené pole. Ostruha má tmavě zelenou ušlechtilou patinu. Jde o jeden z mála exemplářů s výzdobou odlišně provedenou na každém rameni. Rozměry: rozpětí ramen $76-77 \mathrm{~mm}$, v. $84 \mathrm{~mm}, \mathrm{z}$ toho bodec $35 \mathrm{~mm}$, š. ramene nad bodcem 11,1 mm, d. háčku $16 \mathrm{~mm}$. Obr. 4:3.

RFA (tab. 1): Nejspíše nadhodnocen obsah cínu a olova, nebot' nebyly odstraněny korozní produkty. Ostruha mohla být postříbřena, obsah stř́bra není úplně přesvědčivý a pod mikroskopem se nepodařilo nalézt zbytky zachovalého stříbření. Ostruha byla odlita do dvoudílné formy. Zcela nové je zjištění, že háček byl v místě odlomení původně přiletován pájkou - šlo o opravu nebo výrobní proces? Dosud nikde jinde tento jev nebyl zjištěn (tab. 1), a nikdo se tímto jevem nezabýval. Analýzu provedl D. Perlík ze Středočeského muzea v Roztokách.

Pozn.: V blízkosti nálezu ostruhy bylo nalezeno železné drobné nákončí ve tvaru letícího ptáka, to má luxusnější bronzovou obdobu na hradišti v Praze-Butovicích, nejspíše jde o výrobek ovlivněný západní produkcí a datovatelný do 9. století. Trochu odlišná jsou kování-záponky ve tvaru ptáka z Moravy, tam je krk a hlava zvednutá, kování jsou plastičtější. Jestli nález kování může mít vliv na datování ostruhy, je sporné.

1 Průchod mezi oběma hradišti je v šíri ca $3,2 \mathrm{~km}$. 


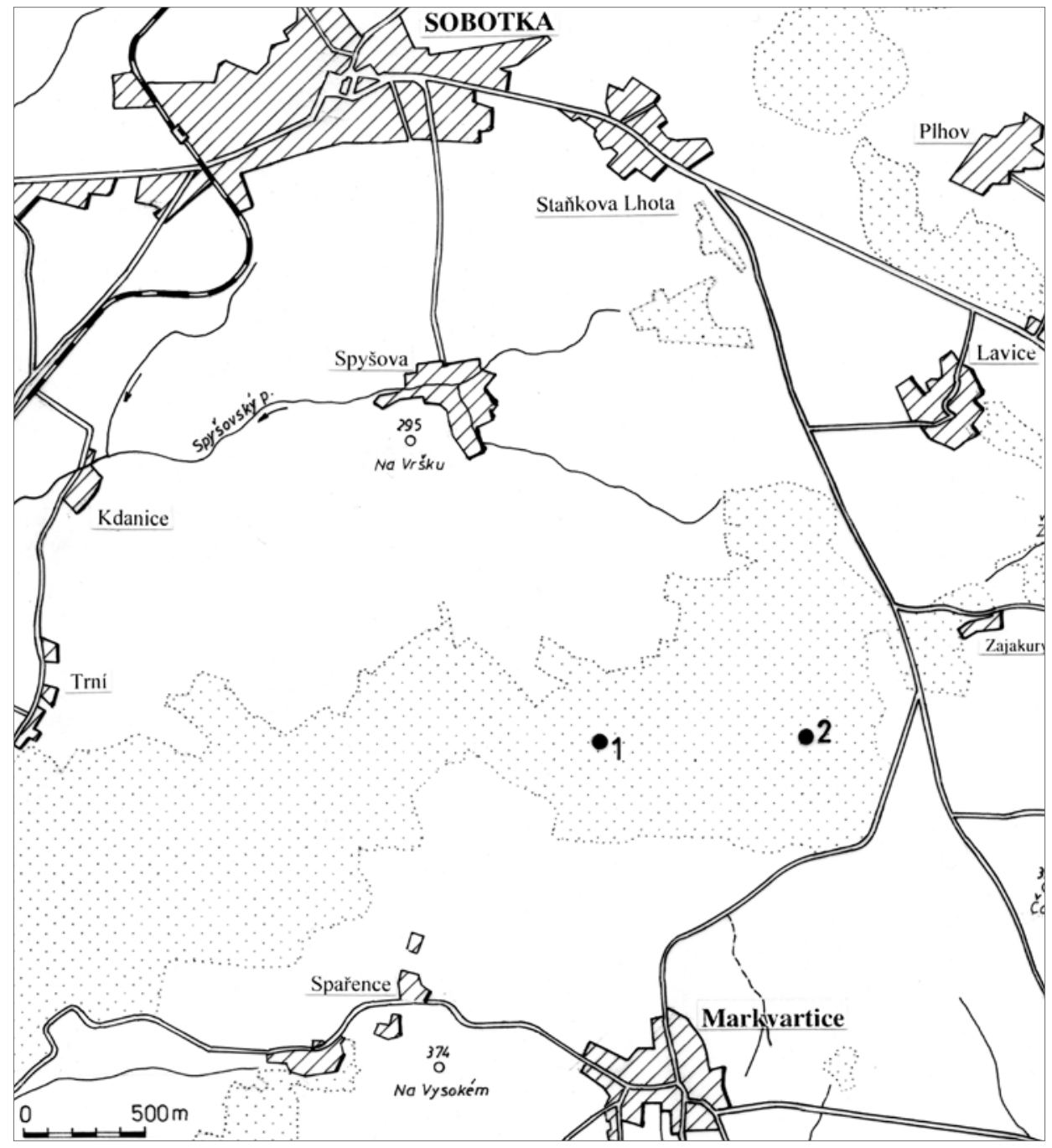

Obr. 1. Sobotka-Spyšova. Místa nálezů. 1 - ostruha, 2 - středohradištní sekera. Grafika H. Minarčíková. Abb. 1. Sobotka-Spyšova. Fundorte. 1 - Sporn, 2 - mittelburgwallzeitliche Axt. Grafik H. Minarčíková.

\section{Sadská, okr. Nymburk}

Tato ostruha byla publikována (naposledy Profantová 1994), poloha v lese Kersko, nezaměřeno. Zjistili jsme však některé detaily, které v starších publikacích nejsou uvedeny.

Popis: Jde o bohatě zdobenou litou ostruhu s hráněným, samostatně připevněným bodcem. Představuje o kvalitní odlitek z dvojdílné formy, opracovaný jen z vnější strany, na vnitřní straně ramen jsou ponechány nálitky. Kromě toho výrobek jasně vypovídá o tom, že háčky byly odlity jen jako zesílení a následně byly vybroušeny - po tomto procesu se zachovaly jasné stopy na obou ramenech. Jsou dobře viditelné hlavně díky odlomení části háčků (obr. 3b). Tyto procesy dokumentuje zvětšená fotografie. Hmotnost: 70 g. Obr. 4:1.

RFA (tab. 1): Měření provedená na vrstvách korozních produktů dokládají, jak při analýze na korozních produktech dochází k výraznému nadhodnocení obsahu stř́bra, cínu a olova. Ostruha byla vyrobena ze slitiny mědi, která obsahuje zinek, cín a olovo. 


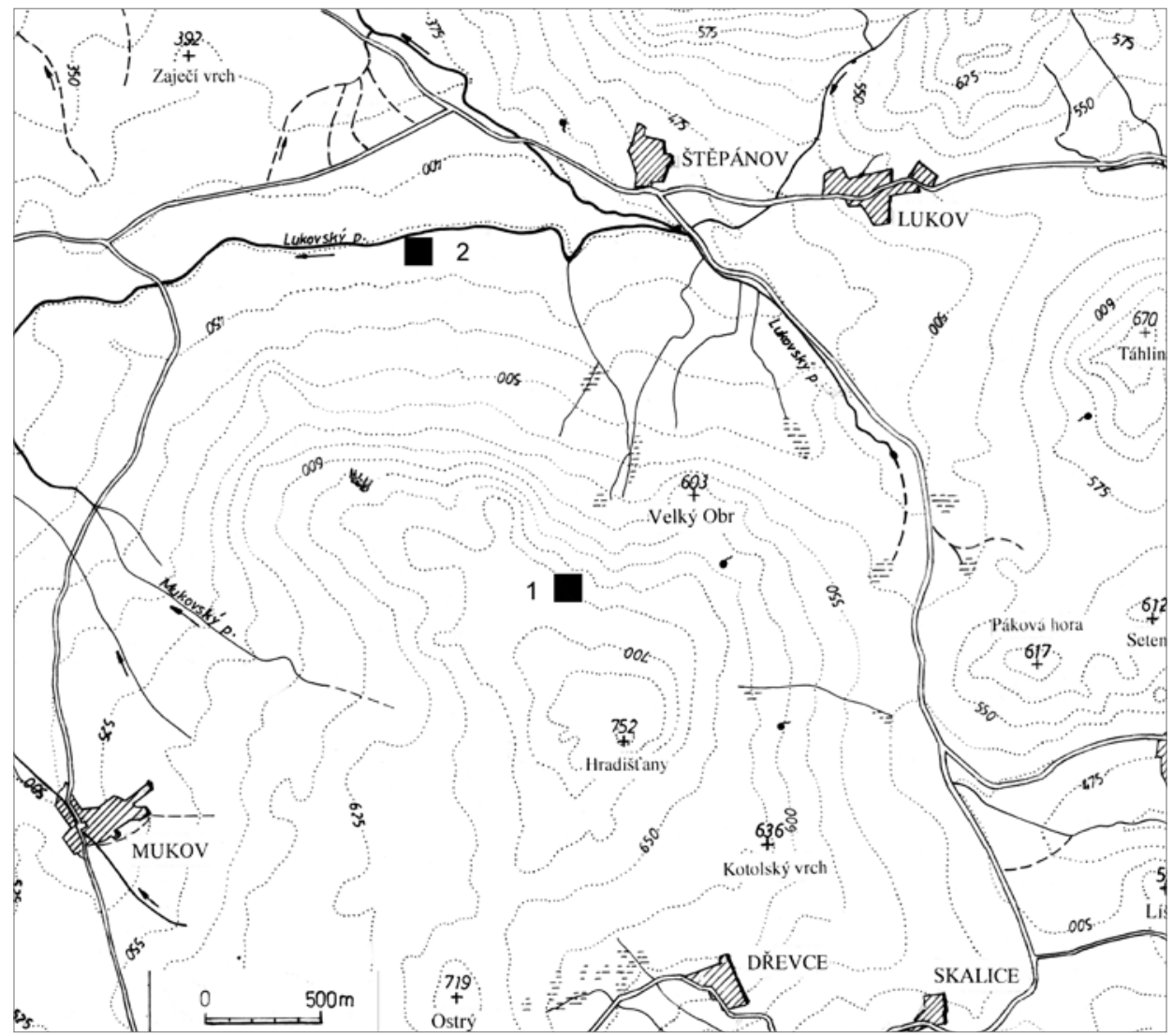

Obr. 2. Místa nálezů ostruh. 1 - Mukov, okr. Teplice, 2 - Štěpánov, okr. Teplice. Grafika H. Minarčíková. Abb. 2. Fundorte der Sporen. 1 - Mukov, Bezirk Teplice, 2 - Štěpánov, Bezirk Teplice. Grafik H. Minarčíková.

\section{Senohraby, okr. Praha-východ}

Ostruha č. 1: V roce 2015 zde byla v hloubce $35 \mathrm{~cm}$ nalezena neúplná bronzová ostruha ca $1000 \mathrm{~m}$ severně-severozápadně od zříceniny hradu Zlenice, poloha Hláska, naproti hradišti Lštění. Zaměření: 4953'6.786" N, 1443'58.188" E. Obr. 3a.

Popis: Litá masivní ostruha s rameny trojúhelníkovitého řezu s pravděpodobně vsazeným bodcem kuželovitého tvaru, odsazeným a zdobeným masivním vývalkem. V místě nad bodcem je rameno zdobeno plastickým obloučkovitým rozšířením a vývalky po jeho stranách. Konec ramene je zdoben rovněž plasticky prohnutým páskem s vývalky pod i nad ním. Neobvyklé je řešení konce ramen. Místo klasického háčku je rameno rozdvojeno (ca $5 \mathrm{~mm}$ ) a do spáry je vsazen, možná i vlepen háček tvořený plechen odlišného složení, ohnutý v délce ca $18 \mathrm{~mm}$. Druhé rameno je odlomeno. Zcela typický není ani vnitřní povrch ostruhy, na němž nebyly broušením odstraněny nálitky, tvořící jistou různě širokou vrstvičku a překrývající možný trn pro nasazení bodce. Na dochovaném rameni ve spodní části je chyba v lití - půlměsíčkové vhloubené místo. Nenarušuje však funkčnost ostruhy. Rozměry: v. $97 \mathrm{~mm}$, z toho bodec $30 \mathrm{~mm}$, max. š. ramene v místě bodce 12,6 mm. Hmotnost: 49 g. Obr. 4:4.

RFA: Vložený plech byl zlacený, či byl vyroben sekundárně ze zlaceného předmětu, ostruha je z olovnatého bronzu.

Ostruha č. 2: Nedaleko zříceniny hradu Zlenice, ca 60-80 m od nálezu č. 1. Zaměření: $49^{\circ} 53^{\prime} 9.7856^{\prime \prime} \mathrm{N}, 14^{\circ} 44^{\prime} 2.610^{\prime \prime}$ E. Obr. 3a. 


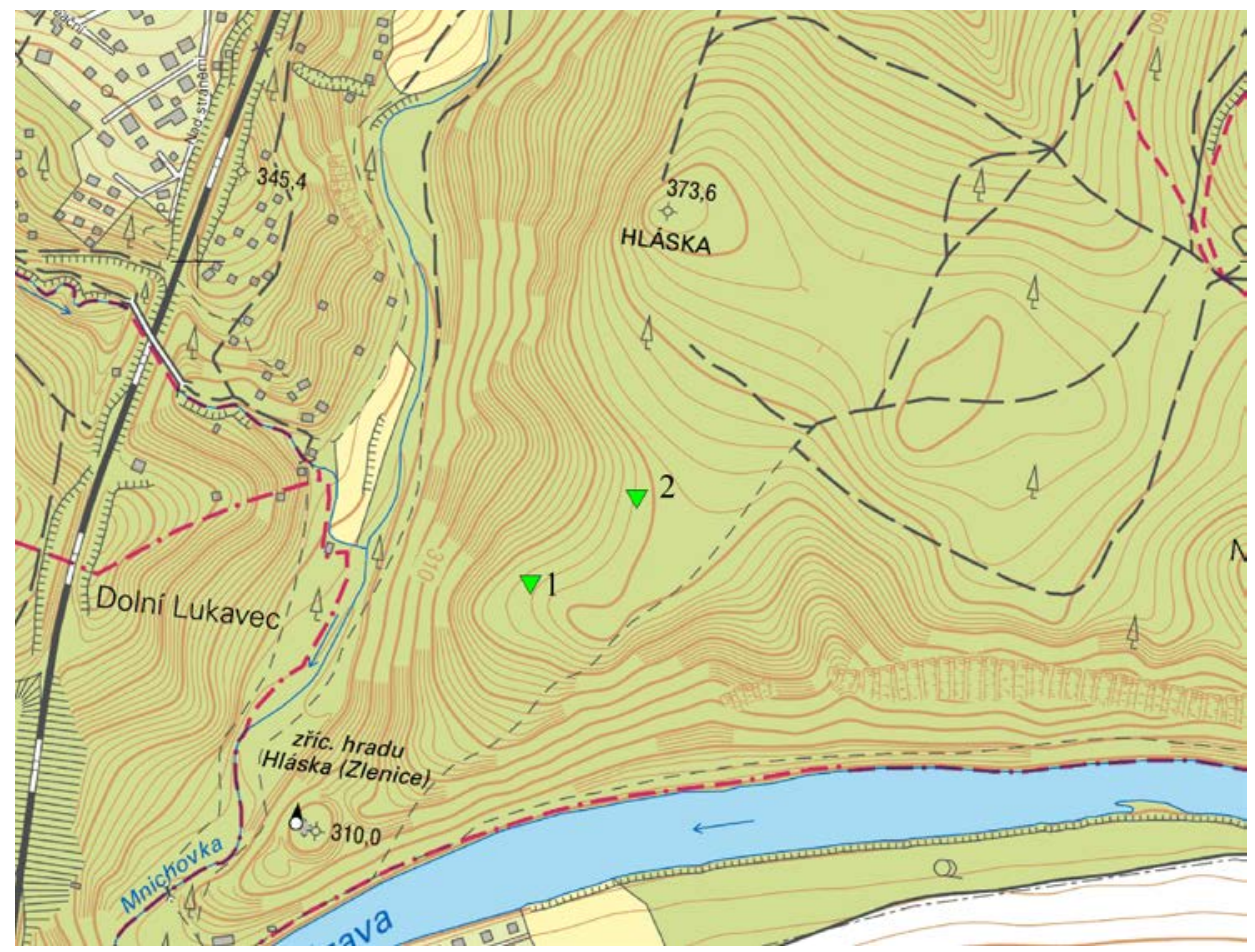

Obr. 3a. Senohraby, okr. Praha-východ. Nálezy ostruh s háčky. Abb. 3a. Senohraby, Bezirk Prag-Ost. Hakensporenfunde.

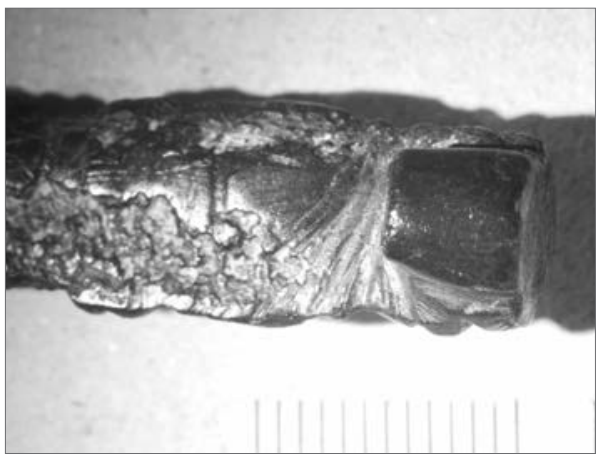

Obr. 3b. Sadská, okr. Nymburk. Detail vnitřní strany ramene ostruhy s nálitkem a stopami výbrusu. Foto D. Perlík. Abb. 3b. Sadská, Bezirk Nymburk. Detail der Bügelinnenseite des Sporns mit Gussüberstand und Schliffspuren. Foto D. Perlík.

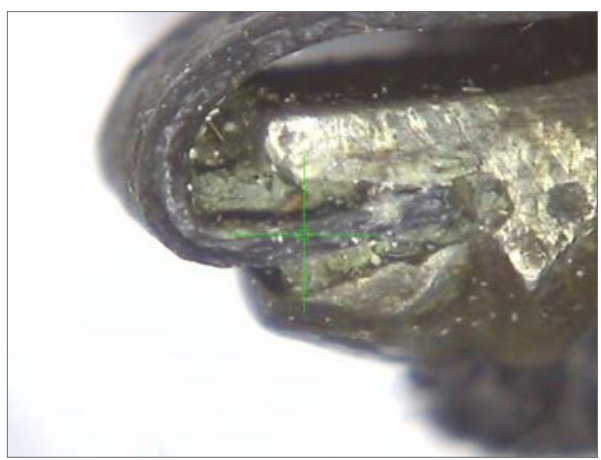

Obr. 3c. Senohraby, ostruha č. 1. Detail opravy ostruhy. Foto M. Fikrle.

Abb. 3c. Senohraby, Sporn Nr. 1. Detail einer Spornreparatur. Foto M. Fikrle.

Popis: Železný exemplář s háčky zahnutými dovnitř, ramena mírně trojúhelníkovitého řezu, složitě profilovaný bodec vsazen a zdoben dvěma zaškrceními, oddělují kulovitou část a kuželovitý zbytek. Rozměry: v. $96 \mathrm{~mm}$, z toho bodec $25 \mathrm{~mm}$. Podle výšky oblouku patř́ k typu D popsanému K. Wachowským (1991, Ryc. 1), tedy k o něco mladším kusům. Obr. 8:6.

Pozn.: Poblíž hradu se též našel v polovině 90. let 20. století raně středověký hrot kopí s dodatečně probitým otvorem v tuleji. Lze jej datovat jen široce do období 8./9.-12. století (Chmielowiec-Kašpar 2011). 


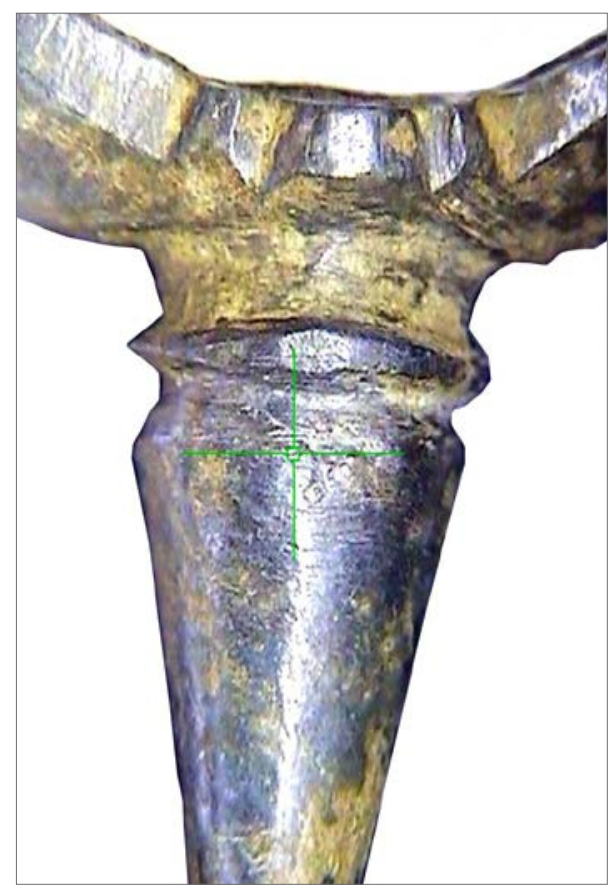

Obr. 3d. Senohraby, ostruha č. 1. Detail výzdoby bodce. Foto M. Fikrle.

Abb. 3d. Senohraby, Sporn Nr. 1. Detail der Dornverzierung. Foto M. Fikrle.

\section{Skorkov, okr. Mladá Boleslav}

Nalezeno 2012-2013 v lese severovýchodně od Staré Boleslavi. Zaměření: 50¹3'23.419" N, 1444'6.868' E. Obr. 7a.

Popis: Bronzová silně zlacená ostruha, nejspíše původně se vsazeným železným trnem (zbytky Fe v otvoru) s rameny jen málo rozevřenými, ukončenými původně háčkem či očkem? Ukončení se ulomilo, je patrné jen zúžení ramene v místě, kde bylo. Ramena jsou zdobena pásy plastických vývalků. Střídá se širší vývalek s devíti úzkými vývalky, které vypadají jako filigránový zaškrcovaný drát, ale nejspíše jsou odlity a dozdobeny. Na konci dochovaného ramene jsou jen čtyři úzké vývalky a z vnitřní strany nasazení háčku/ očka, jeho zbytek byl odlomen. Rozměry: v. $114 \mathrm{~mm}$, průměr otvoru pro trn $5-6 \mathrm{~mm}$, předpokládané rozpětí oblouku $85 \mathrm{~mm}$. Hmotnost: 37 g. Obr. 7b; 12:1.

RFA: Ostruha je z bronzu s $15 \%$ cínu, se zinkem, arsenem a olovem, tvořícími sumárně přibližně $9 \%$ slitiny. Zlacení proběhlo amalgamací.

Pozn.: V blízkosti nálezu se našly slitky barevného kovu, jeden analyzován pomocí RFA.

\section{Tismice, okr. Kolín}

Hradiště centrálního významu o ploše zhruba 20 ha, s největši koncentrací bronzových okras doby avarské v Čechách (více než 100 ks, srov. Profantová-Stolz 2006; Militký-Profantová-Videman 2013). V letech 2014-2015 se teprve při druhém a třetím systematickém průzkumu hradiště s pomocí detektoru kovů, provedeném ARÚ AV ČR, Praha, v. v. i. (N. Profantová) se podařilo nalézt zlomky tří bronzových ostruh, dva z nich představovaly jen ozdobné ukončení ramen. Všechny zlomky jsou zaměřeny a pocházejí z předhradí, vzdálenosti mezi zlomky jsou výrazné, jejich poloha bude detailně vyhodnocena spolu s ostatními nálezy.

Popisy:

Pořadové č. 208, přírůstkové č. 78/014: Litý bronzový zbytek ostruhy s háčky, zdobený žlábky vedoucími z obou stran do středu ostruhy, na konci je hladká ploška, z vnitřní strany projmutá, tam byl zřejmě nyní odlomený háček. Rozměry: dochovaná d. $17 \mathrm{~mm}$, š. ramene $9 \mathrm{~mm}$. Obr. 10:3.

Pořadové č. 209, přírůstkové č. 80/014: Litý bronzový zbytek ostruhy s háčky, zdobený pásy $\mathrm{s}$ vývalky a s dochovaným háčkem z vnitřní strany. Rozměry: dochovaná $\mathrm{d}$. $23 \mathrm{~mm}$, š. ramene $8 \mathrm{~mm}$. Hmotnost: 6 g. Obr. 10:1.

Přírůstkové č. 609/015: Bronzová litá neúplná ostruha - původně s háčky. Měla vsazený bodec, po němž zbyl otvor a kruhové rozšíření ramene. Rozměry: š. ramene $8 \mathrm{~mm}$. Hmotnost: 11 g. Obr. 10:4.

RFA: Zlomek z roku 2015 byl předán na analýzu, výsledek je v tab. $1 b$.

Pozn.: K nálezům ostruh funkčně nejspíše patří bronzová karolinská průvlečka s plastickými vývalky obdobného stáří (obr. 10:2), na Západě se vyskytuje častěji s ostruhami s vyšším obloukem (např. Gabriel 1981, Abb. 2) - obdobných typů, jako je ostruha ze Skorkova. Všechny nálezy ukazují na pohyb jezdců po hradišti. 


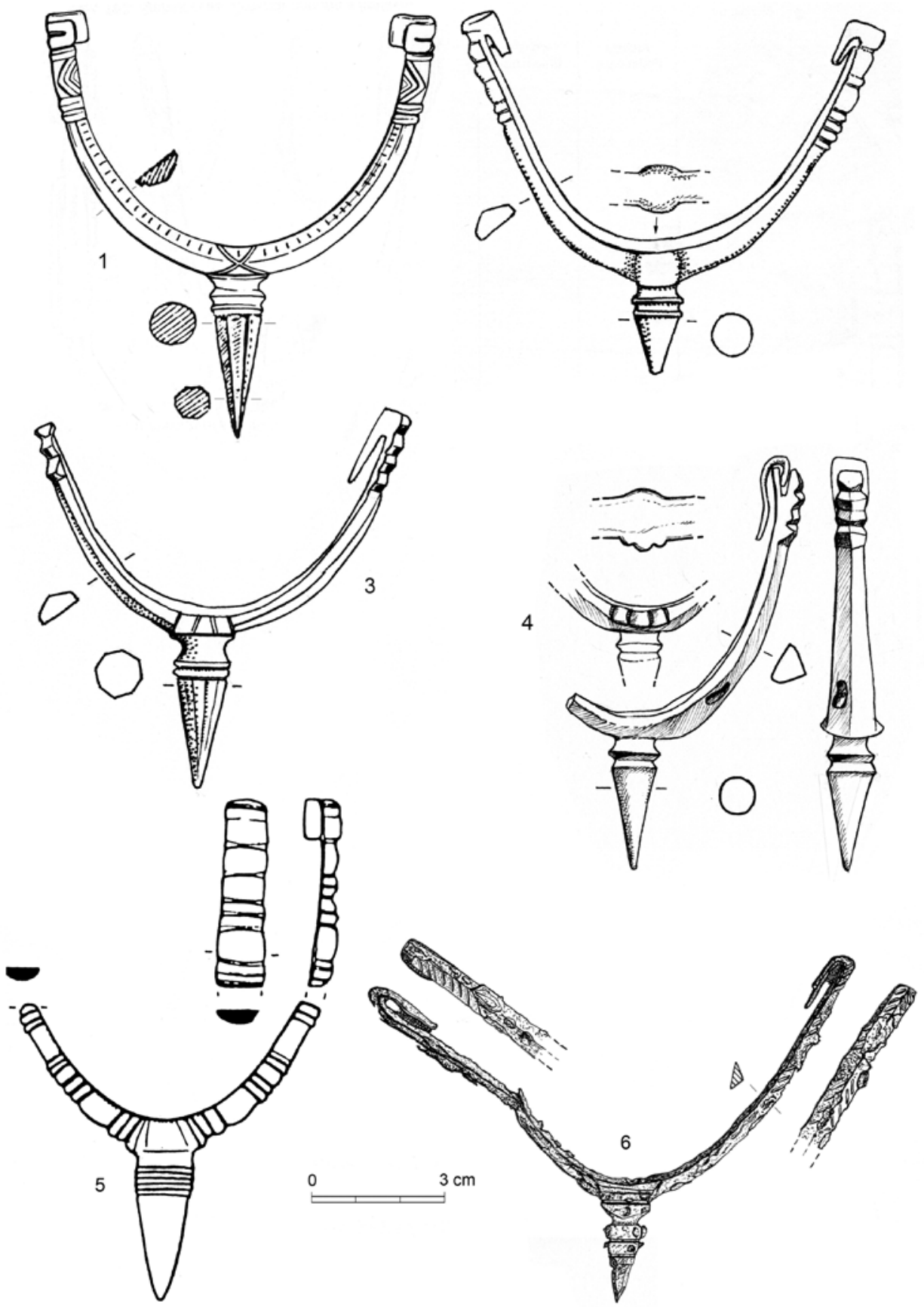

Obr. 4. Bronzové a zdobené železné ostruhy s háčky v Čechách. 1 - Sadská, okr. Nymburk; 2 - Sobotka-Spyšova, okr. Jičín; 3 -Mukov, okr. Teplice; 4 -Senohraby, okr. Praha-východ; 5 -Strakonice, okr. Strakonice; 6 - Sekeřice/Osek, okr. Nymburk. 1-5 - bronz, 6 - cínované železo. Podle Profantová 2015, Fig. 4 (1-3, 5, 6); kresba (4) L. Raslová.

Abb. 4. Hakensporen aus Bronze und verzierte Hakensporen aus Eisen in Böhmen. 1 - Sadská, Bezirk Nymburk; 2 -Sobotka-Spyšova, Bezirk Jičín; 3 - Mukov, Bezirk Teplice; 4 - Senohraby, Bezirk Prag-Ost; 5 - Strakonice, Bezirk Strakonice; 6 Sekeřice/Osek, Bezirk Nymburk. 1-5 - Bronze, 6 - verzinntes Eisen. Nach Profantová 2015, Fig. 4 (1-3, 5, 6); Zeichnung (4) L. Raslová. 


\section{B Železné kusy}

Zvlášt' popíšeme železné ostruhy, těch přibylo devět z šesti lokalit. Jsou sociálně méně výlučné, zahrnují početněji domácí výrobky. Jejich koncentrace však poskytují též sociální výpověd'.

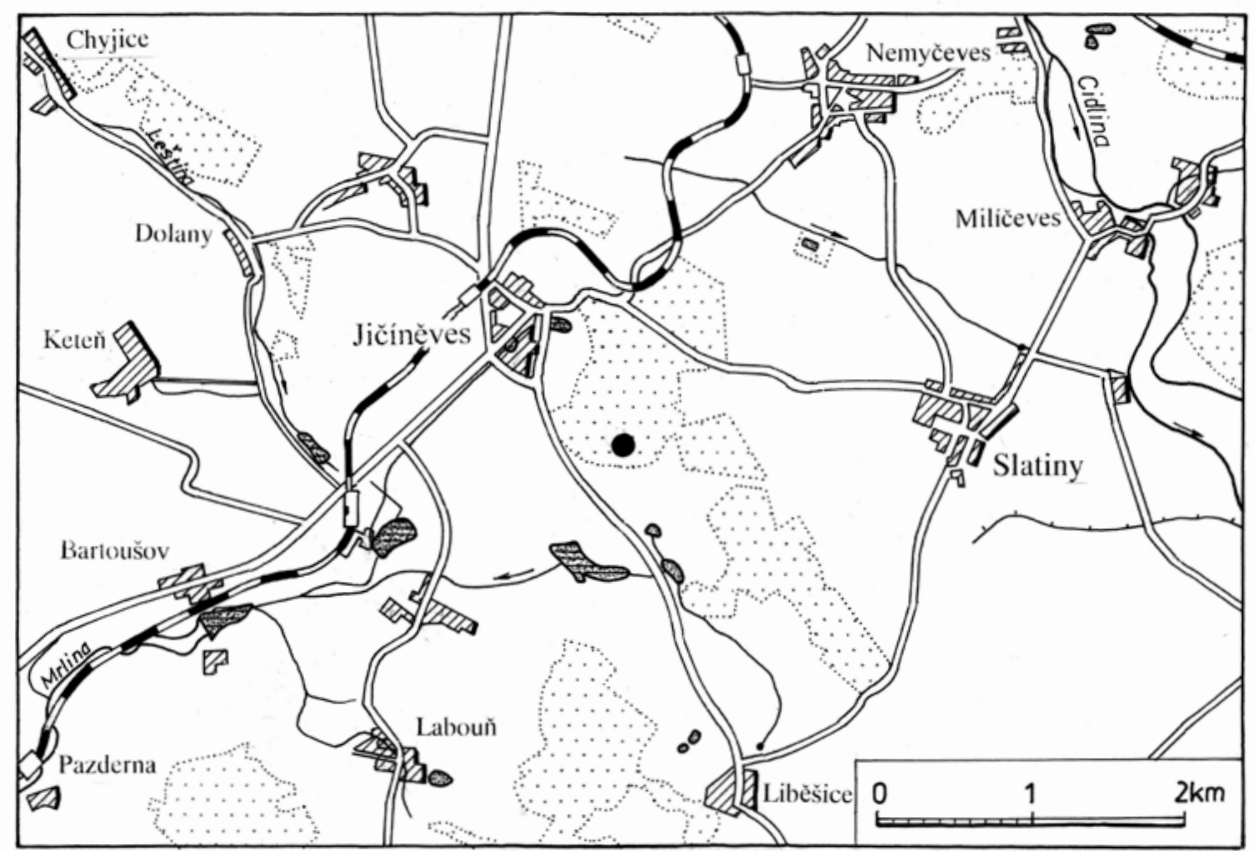

Obr. 5a. Jičíněves, okr. Jičín. Místo nálezu ostruhy.

Abb. 5a. Jičíněves, Bezirk Jičín. Fundort des Sporns.

\section{Jičiněves, okr. Jičín}

Nalezeno jihovýchodně od vsi, les Obora, při lesní cestě vedoucí k potoku. Zaměření: $50^{\circ} 21^{\prime} 54.632^{\prime \prime} \mathrm{N}, 15^{\circ} 20^{\prime} 55.498^{\prime \prime}$ E. Obr. 5a.

Popis: Železná ostruha s dovnitř zahnutými háčky byla vyrobena $\mathrm{z}$ tyčinky obdélného na vnější straně zaobleného průřezu. Bodec je zdoben obdélným zesílením pod ramenem ostruhy, poté je oble hráněný. Rozměry: d. bodce $25 \mathrm{~mm}$, v. ramene ostruhy $81 \mathrm{~mm}$. Obr. $5 b$.

\section{Mořinka, okr. Beroun}

Výšinná ostrožná poloha, snad pravěké hradiště nad obcí Karlík, podrobně nepopsaná, s dvojicí terénních pozůstatků, které mohly být zbytkem lehčího opevnění. Osídlení je doloženo z pozdní doby bronzové, halštatské,

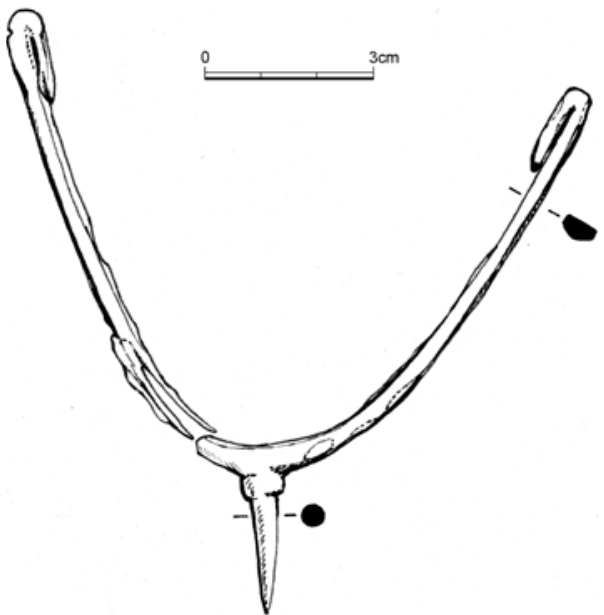

Obr. 5b Jičíněves, okr. Jičín. Podle Profantová 2015, Fig. 4. Abb. 5b Jičíněves, Bezirk Jičín. Nach Profantová 2015, Fig. 4. laténské a raného i vrcholného středověku. Mezi chronologicky citlivé raně středověké nálezy patř́i litá kování pozdní doby avarské a ostruhy s háčky. Všechny tyto nálezy pocházejí z „akropole“ 
(Profantová v tisku a, Abb. 11a, b). Ostruha č. 1 byla nalezena v mírném svahu ještě na akropoli (směrem k valu, B. 385) v roce 2014; ostruha č. 2: bod č. 418 blíže hrany akropole, v nadmořské výšce $345 \mathrm{~m}$ a hloubce $24 \mathrm{~cm}$. Vzdálenost mezi oběma nálezy je ca 112-113 m.

Popisy:

Ostruha č. 1: Cínovaná železná ostruha s dovnitř ohnutými háčky, jeden háček částečně dochován. Bodec vsazen zvlášt' (rtg snímek) a je téměř dvojkuželovitého, resp. dvojkónického tvaru. Rozměry: v. 90 mm, d. bodce $28 \mathrm{~mm}$. Obr. 8:7.

Literatura: Profantová 2015, obr. 5:I.1, v seznamu nálezů z lokality č. 10.

Ostruha č. 2: Neúplná ostruha s háčky zahnutými dovnitř a kuželovitým bodcem zdobeným třemi vhloubenými rýhami. Ramena jsou lehce trojúhelníkovitého průřezu. Rozměry: v. $100 \mathrm{~mm}$, z toho bodec 32,4 mm. Rtg snímek ukázal, že bodec je vsazený. Obr. 8:4.

Pozn.: Č. 40 v nepublikovaném popisu nálezů z lokality. Nepublikováno.

\section{Sekerice/Osek, okr. Nymburk}

Ostruha č. 1: Uvnitř areálu pravěkého hradiště v poloze Na Kostelíku či Na Kostele, při jeho severozápadní hraně (obr. 6a), v roce 1999 nalezla K. Motyková - zřejmě tatáž ostruha, kterou nálezkyně zmiňuje jako „Chroustov, okr. Nymburk“ (Profantová 2016, Abb. 11:2), soudě dle jejího zaměření místa nálezu. Obr. 6.

Popis: Ostruha zdobená na ramenech žlábky vytvářejícími „, $\mathrm{V}^{\prime}$ měla zdobený a silně profilovaný i bodec pyramidkového tvaru s žlábkem a oddělenou základnou. Rozměry: v. $80 \mathrm{~mm}$, d. bodce $25 \mathrm{~mm}$. Obr. 4:6

RFA: Ostruha byla pocínována, ovšem nikoli čistým, poněkud nákladnějším cínem, ale směsí cínu a olova v poměru $4: 1$. RFA provedena v roce $2012 \mathrm{v}$ muzeu v Roztokách, dodatečně proveden i rtg snímek.

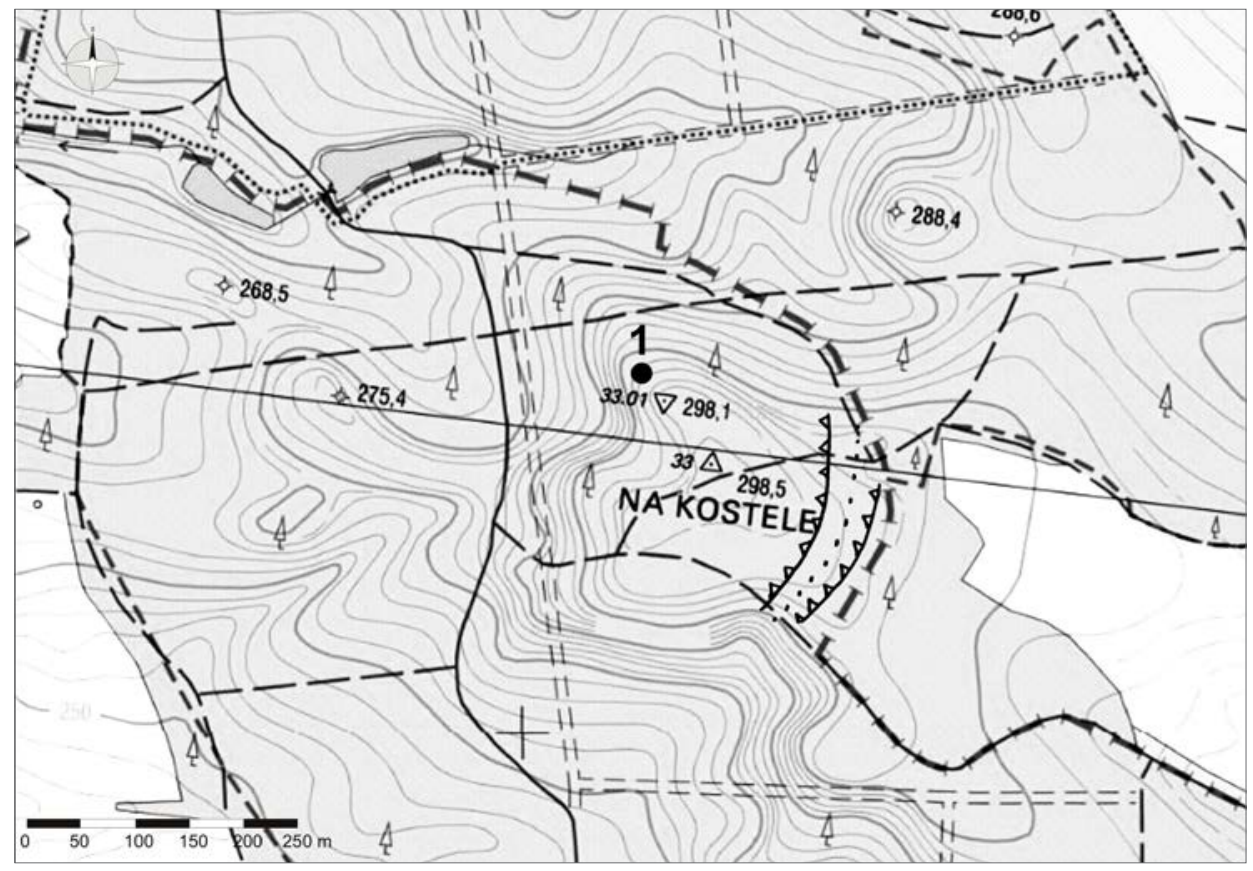

Obr. 6a. Sekeřice/Osek, okr. Nymburk, poloha Na Kostele. Zaměření nálezu ostruhy č. 1. Podle K. Motykové, nepublikováno a podle Profantová 2015.

Abb. 6a. Sekeřice/Osek, Bezirk Nymburk, Lage Na Kostele. Vermessung des Fundes von Sporn Nr. 1. Nach K. Motyková unpubliziert und nach Profantová 2015. 
Pozn.: To je druhý případ pocínování ostruhy s háčky v České republice (viz Brno-Líšeň, nově i další ostruha Sekeřice), až se masově provedou analýzy, bude to běžnější jev. ${ }^{2}$

Ostruha č. 2: Nezaměřena, nalezena před rokem 2011.

Popis: Železná ostruha s ven vyhnutými háčky tvořícími očka a s vyšším obloukem a drobným bodcem. Rameno je vykováno z plochého pásku. Rozměry: v. 113/4 mm, bodec $7 \mathrm{~mm}$, š. ramene $4 \mathrm{~mm}$. Obr. 6b; 11:II.b.

Literatura: Profantová 2015, Fig. 5: II.2; v tisku, Abb. 11:1.

Pozn.: Ostruha představuje nový typ v Čechách a byla sem nejspíše importována z karolinské oblasti.

Ostruha č. 3. V roce 2013 se našla další neúplná ostruha. Zaměření: N 50.287.10, E 15.37222 (J. Skala).

Popis: Ostruha bez ukončení, drobnějších rozměrů, takže odpovídá bud' ostruhám s háčky či očky, u ní prokázáno též cínování

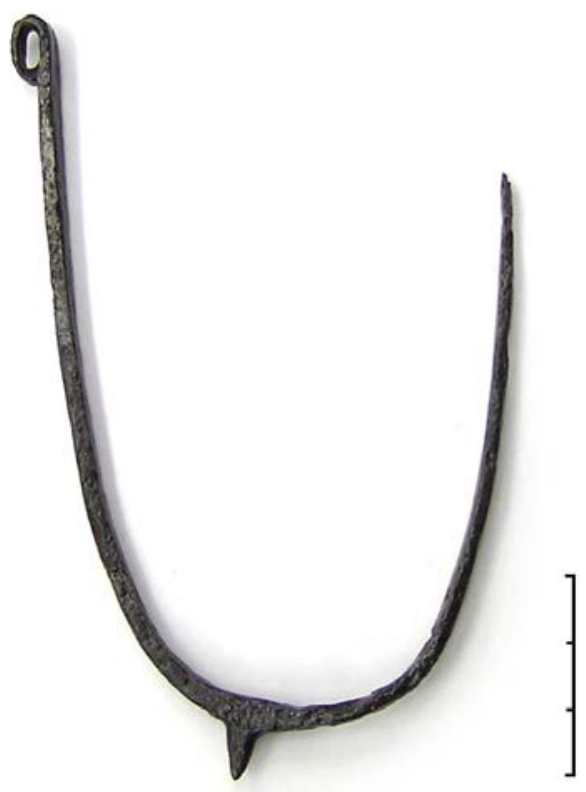

Obr. 6b. Sekeřice/Osek, okr. Nymburk, poloha Na Kostele. Abb. 6b. Sekeřice/Osek, Bezirk Nymburk, Lage Na Kostele. (obr. 8:1). ${ }^{3} \mathrm{Na}$ rtg. snímku je vidět vsazený bodec a náznak jakési pravidelné plastické (?) výzdoby ramen. Výška je neúplná, ramena ve tvaru U.

Pozn.: Kromě této ostruhy se na hradišti našel hrot kopí a větší počet hrotů šípů (minimálně 9 ks, převážně s křidélky a tulejkou). Několik šipek bylo koncentrováno ve svahu blíže nálezu ostruhy č. 1. Také se tam našla dvě kování avarského typu, z nichž jen jedno bylo zaměřeno.

\section{Sv. Jan pod Skalou, okr. Beroun}

Ostruha č. 1: Nalezena v roce 2015, objevena těsně pod akropolí hradiště (k hradišti Benková-Čtverák 1998). ${ }^{4}$ Zaměření: 4957'57.53" N, 148'8.46" E.

Popis: Železná ostruha s háčky ohnutými dovnitř a vsazeným bodcem, jedno rameno na konci zdobeno motivem „, $V^{\prime}$ žlábků, na kratším je patrný jen jeden. Ramena jsou střechového průřezu. Zajímavé je zeslabení (projmutí) ramen v místě háčků, mohlo se snadněji zlomit při namáhání. Rozměry: v. $72 \mathrm{~mm}$, z toho bodec 13,5 mm, rozpětí ramen $71 \mathrm{~mm}$. Obr. 8:5.

Pozn.: V seznamu nálezů z lokality má č. 78.

Ostruha č. 2: Již roku 2014 byla objevena ve svahu při hradišti, zaměřena jako B. 426.

Popis: Další masivnější ostruha s plochými páskovými rameny, vysokého oblouku, se zvlášt' zvnějšku vsazenými pocínovanými tyčinkovitými konci ramen s háčky zahnutými dovnitř. Relativně delší a užší jehlanovitý bodec je též vsazený (vyplývá to z rtg. snímků). Rozměry: v. $140 \mathrm{~mm}, \mathrm{z}$ toho trn $37 \mathrm{~mm}$. Obr. 8:3. V seznamu nálezů z lokality pod číslem 3.

Pozn. Tvoří samostatnou, asi i mladší variantu typu I.1. (obr. 11; Profantová 2015, fig. 5:I.1.C).

Ostruha č. 3: Z hradiště pochází ještě hráněný bodec k ostruze, byl původně vsazen a je zdoben plastickými vývalky v horní části - směrem k ramenům. Rozměry: v. 40 mm, š. zbytku ramene $7 \mathrm{~mm}$. Obr. 8:2.

\footnotetext{
2 Už nyní jsou zdokumentovány minimálně další tř̆i až čtyři příklady z 8. století a 1. poloviny 9. století.

3 Děkuji J. Skalovi za možnost zlomek použít.

4 Autorka připravuje studii o novém souboru raně středověkých nálezů včetně kování avarského typu.
} 


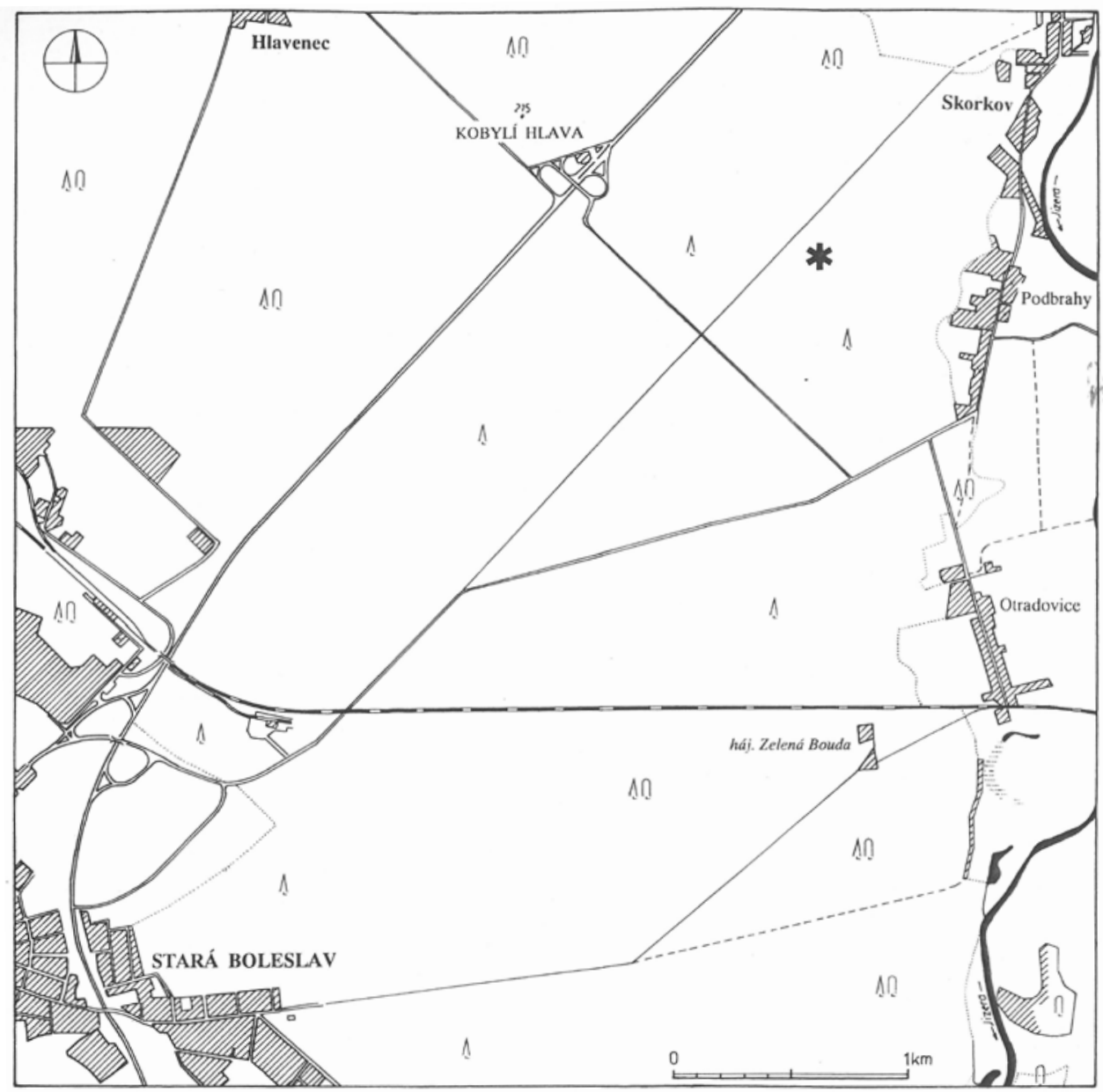

Obr. 7a. Skorkov, okr. Mladá Boleslav. Místo nálezu ostruhy.

Abb. 7a. Skorkov, Bezirk Mladá Boleslav. Fundort des Sporns.

Pozn.: Ostruha mohla být bud' typu a varianty jako předchozí č. 2, nebo ukončená nýtky či ploténkami s nýtky. Obdobu má např. v ostruze s háčky z Brna-Líšně, č. 900/54 (Kouřil ed. 2014, 303).

Nejspíše všechny tři kusy z lokality představují krátký časový interval.

\section{1. Štěpánov, okr. Teplice}

V únoru 2013 nalezeno v lese „Liščí díry“ poblíž lesní cesty, v hloubce ca $15 \mathrm{~cm}$ v jílovité půdě. Obr. 2:2.

Popis: Železná ostruha s ven vyhnutými háčky a kratším kuželovitým výrazně odsazeným bodcem, nejspíše nebyla vyrobena vcelku - z rtg snímku nelze jednoznačně určit. Ostruha byla zdobena na koncích ramen vodorovnými rýžkami ve vzdálenosti 3-5 mm od sebe, výzdoba je zrretelná i u bodce, mohla pokrývat i celá ramena. Nad připojením bodce, ve středu oblouku je patrné zdobení v podobě dvou diagonálně překř́ižených rýžek, připomínající písmeno $\mathrm{X}$. To je výzdobný motiv známý z bronzových ostruh (Sadská). Rozměry: v. 78, resp. $80 \mathrm{~mm}$, z toho bodec $12 \mathrm{~mm}$. Hmotnost: 15,1 g. Obr. 11:I.1.2a. 
Literatura: Štolba-Rypka 2014; ${ }^{5}$ Profantová 2015, fig. 4:5.

Diskuse: V blízkosti probíhala komunikace (nálezy podkov, ostruh a mince) spojující Hradišt’any a Radovesice, dosavadní doklady se vázaly na vrcholný středověk až 16 . století. Zmíněná ostruha by mohla být dokladem existence komunikace již v 8. století.

12. V̌sestary, poloha Chlum u Hradce Králové, okr. Hradec Králové

V roce 2014 nalezeno $\mathrm{v}$ prostoru známé bitvy u Hradce (1866), v hloubce ca $40 \mathrm{~cm}$.

Popis: Ostruha s ven vyhnutými háčky a vsazeným kuželovitým bodcem. Na ramenech jsou stopy po příčných žlábcích $\mathrm{v}$ rozestupech $5 \mathrm{~mm}$. Ostruha již byla ošetřena elektrolýzou, takže nebyl podrobně zkoumán povrch. Rozměry: v. $103 \mathrm{~mm}, \mathrm{z}$ toho bodec $22 \mathrm{~mm}$, levé rameno je vyšší než pravé, d. háčku 20 mm. Obr. 11:I.2.b

Literatura: Profantová 2015, Fig. 5: I.2b, ostruha představuje novou variantu na území Čech.

Pozn.: Údajně z téhož prostoru má pocházet i zlacená ostruha staršího typu, ovšem nevíme, s jakým ukončením, nepodařilo se ji zdokumentovat. Nález ostruhy ve strategické poloze využité později $\mathrm{k}$ vojenskému střetu naznačuje, že tuto polohu využili lidé již koncem 8., či spíše v první třetině 9 . století.

\section{C Vybrané nové nálezy z Moravy}

Tento exkurz připojuji proto, že v př́ípadě dvou až tří neúplných kusů ostruh s háčky z hradiště Brno-Líšeň jsme získali též nový a podle nás důležitý technologický poznatek. Jedna z ostruh této lokality - č. 3 (obr. 15:1) byla pocínována, stejně jako dále zmíněná ostruha z Roštína. Ostruha č. 1 byla též podrobena analýze RFA, která byla provedena v ÚJF AV ČR v Řeži. Stejné postupy tedy umožňují kvalitní technologická srovnání. ${ }^{6}$
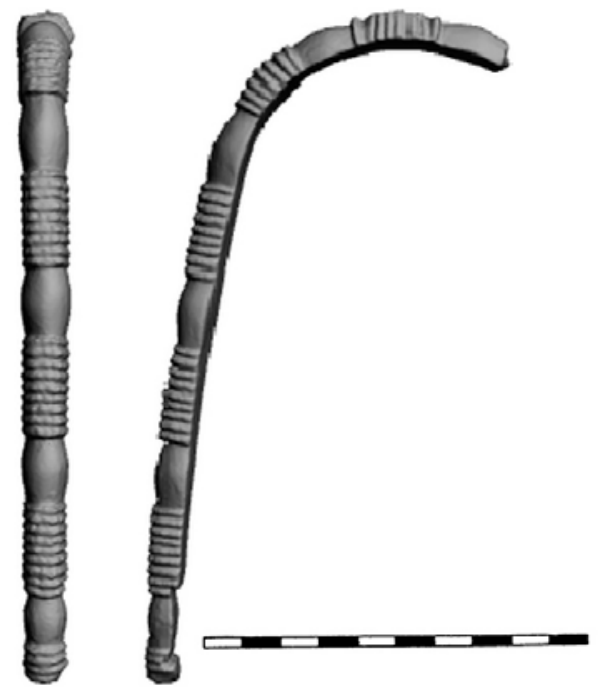

Obr. 7b. Skorkov, okr. Mladá Boleslav. 3d snímek/model prof. K. Pavelka, FS ČVUT Praha.

Abb. 7b. Skorkov, Bezirk Mladá Boleslav. 3d-Aufnahme/ Modell - Prof. K. Pavelka, Fakultät für Maschinenbau der Technischen Universität Prag.

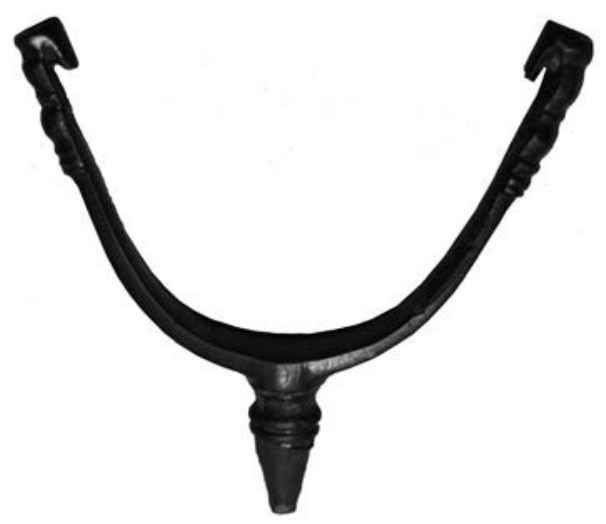

Obr. 7c. Sobotka-Spyšova, okr. Jičín. Detail výzdoby. Abb. 7c. Sobotka-Spyšova, Bezirk Jičín. Verzierungsdetail.

5 Ostruha sice byla nedávno publikována, ale je potřeba $\mathrm{k}$ dalšímu hodnocení.

6 Nový soubor ostruh z Moravy má v tisku P. Koư̌il, avšak nevím, jak rozsáhlý je podíl nových nálezů. 


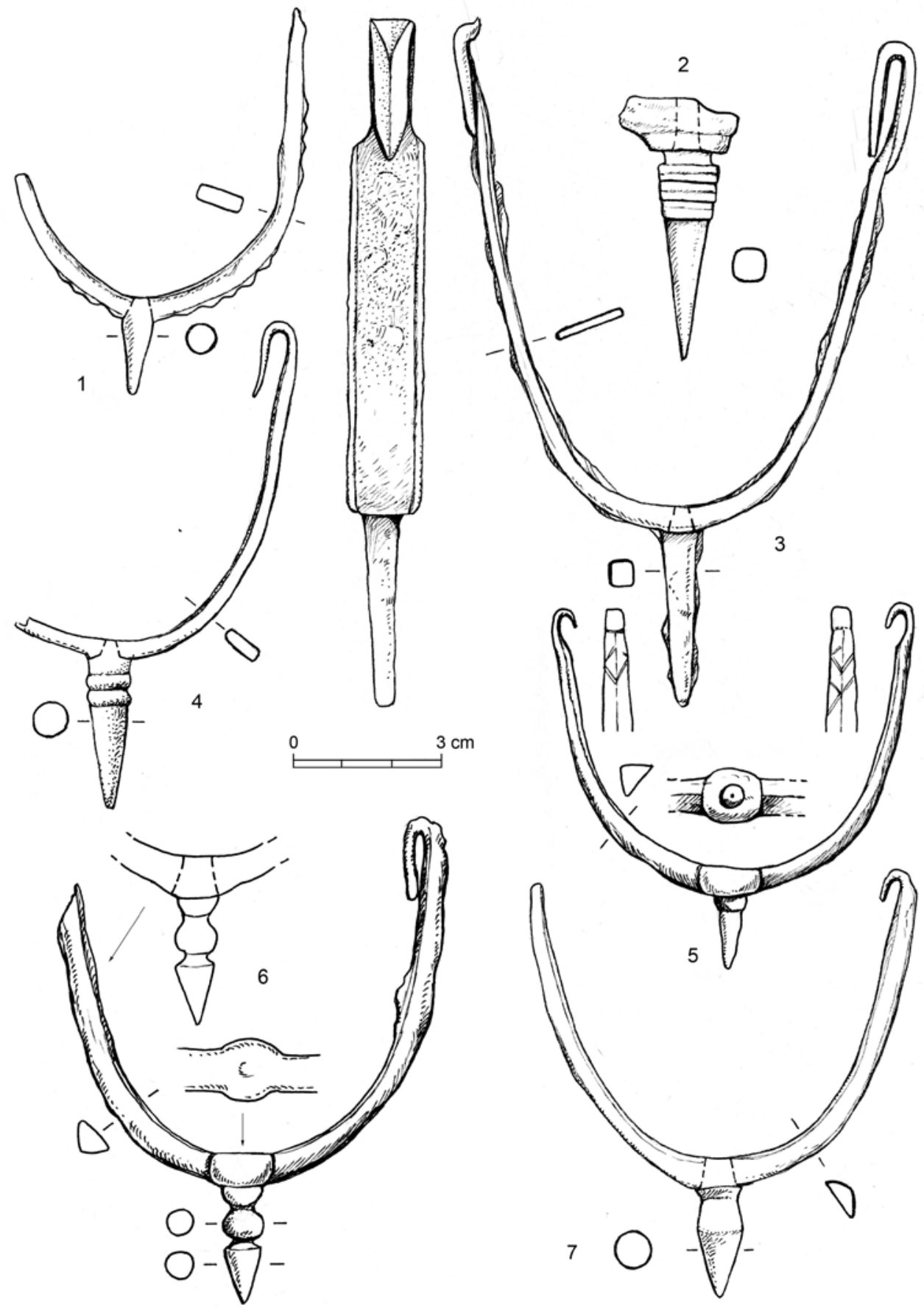

Obr. 8. Ostruhy s háčky se vsazeným bodcem. 1 - Sekeřice, okr. Nymburk, neúplná ostruha č. 3; 2-3, 5- Sv. Jan pod Skalou, okr. Beroun; 4, 7 - Mořinka, okr. Beroun; 6 - Senohraby, okr. Praha-východ č. 2; 2-5 - železo, 1 , 7 - cínované železo. Kresba L. Raslová; podle Profantová 2015, fig. 5 (3).

Abb. 8. Hakensporen mit eingesetztem Dorn. 1 - Sekeřice, Bezirk Nymburk, unvollständiger Sporn Nr. 3; 2-3, 5 - Sv. Jan pod Skalou, Bezirk Beroun; 4, 7 - Mořinka, Bezirk Beroun; 6-Senohraby, Bezirk Prag-Ost Nr. 2; 2-5 - Eisen, 1, 7 - verzinntes Eisen. Zeichnung L. Raslová; nach Profantová 2015, Fig. 5 (3). 


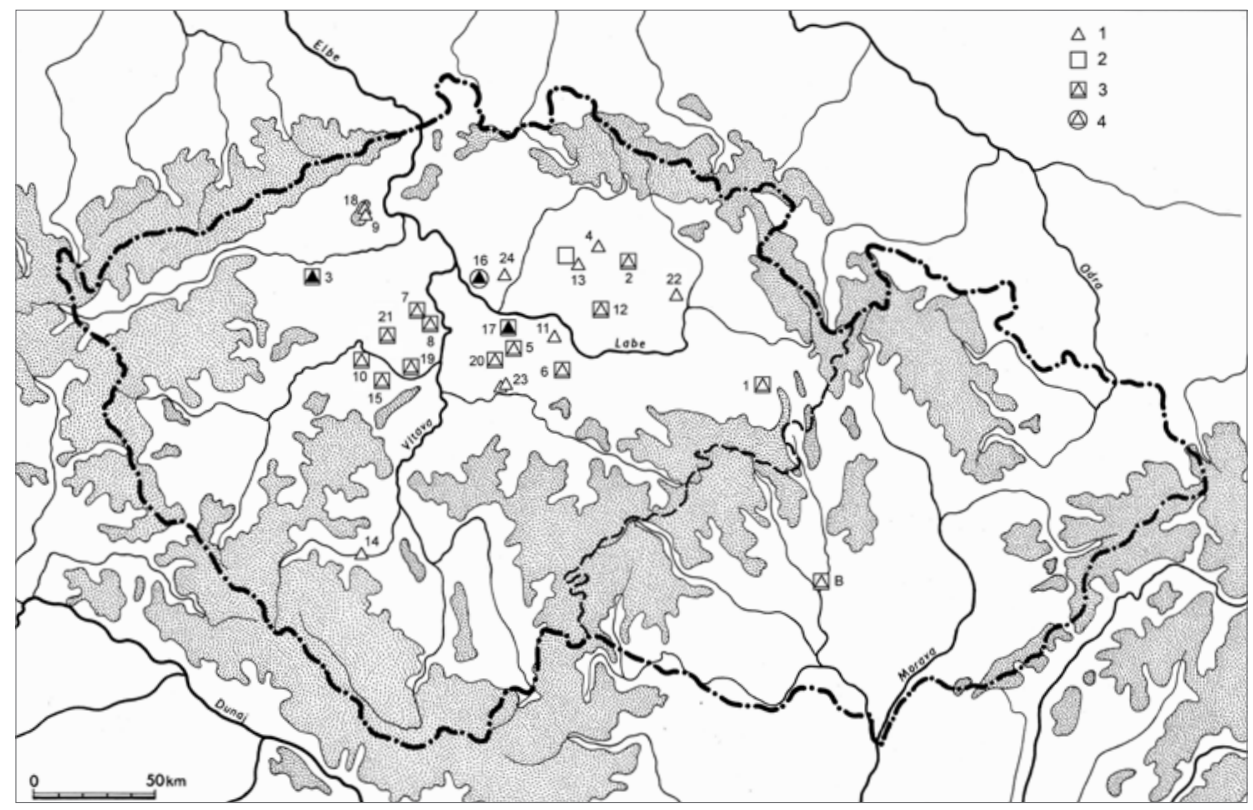

Obr. 9. Čechy, nálezy ostruh s háčky. 1 - nález ostruhy s háčky, 2 - hradiště, 3 - nález na hradišti, 4 - nález na sídlišti. Vyplněný trojúhelník - tř̌i a více nálezů ostruh. Lokality: 1 - Benátky, 2 - Češov, 3 - Dolánky-Rubín, 4 - Jičíněves-les, 5 Klučov (háčky odlomeny), 6 - Kouřim, 7 - Kováry-Budeč, akropole, 8 - Levý Hradec - neúplná, 9 - Mukov, 10 - Otmíče, asi Otmíčská hora, 11 - Sadská (les Kersko), 12 - Sekeřice, 13 - Sobotka-Spyšova a hradiště Vesec, 14 - Strakonice, 15 - Tetín (ztracena), 16 - Tišice, 17 - Toušeň, 18 - Štěpánov, 19 - Mořinka, 20 - Tismice, 21 - Sv. Jan pod Skalou, 22 - Všestary-Chlum, 23 - Senohraby, 24 - Skorkov; B - Brno-Líšeň, odkud předkládáme nové exempláře.

Abb. 9. Böhmen, Funde von Hakensporen. 1 - Hakenspornfund, 2 - Burgwall, 3 - Burgwallfund, 4 -Siedlungsfund. Schwarzes Dreieck - drei und mehr Sporenfunde. Fundstellen: 1 - Benátky, 2 - Češov, 3 - Dolánky-Rubín, 4 - Jičíněves-Wald, 5 - Klučov (Haken abgebrochen), 6 - Kouřrim, 7 - Kováry-Budeč, Gräberfeld, 8 - Levý Hradec - unvollständig, 9 - Mukov, 10 - Otmíče, wahrscheinlich Berg Otmíčská hora, 11 - Sadská (Kersko-Wald), 12 - Sekeřice, 13 - Sobotka-Spyšova und Burgwall Vesec, 14 - Strakonice, 15 - Tetín (verloren), 16 - Tišice, 17 - Toušeň, 18 - Štěpánov, 19 - Mořinka, 20 - Tismice, 21 - Sv. Jan pod Skalou, 22 - Všestary-Chlum, 23 - Senohraby, 24 - Skorkov; B - Brno-Líšeň, von wo die neuen, von uns vorgelegten Exemplare stammen.

\section{Brno-Lí̌̌en̆, okr. Brno- město}

Vícedílné hradiště doloženo od konce 8 . století přes dobu velkomoravskou až do doby mladohradištní (naposledy Měřínský 2014). Nalezeno před rokem 2009.

Popisy:

Ostruha č. 1: Nalezeno v části hradiště (čtvrtině) označené písmenem $\mathrm{D}$, tedy $\mathrm{v}$ jihovýchodní části akropole. Zlomek ramene lité bronzové ostruhy s háčky zdobené plastickou (dva plošší vývalky na konci ramene) a rytou výzdobou, nejvýrazněji na konci ramen. Rozměry: dochovaná v. ramene trojúhelníkovitého průřezu $50 \mathrm{~mm}$, d. háčku $12 \mathrm{~mm}$, š. 9-10 mm. Obr. 15:3. Datováno do druhé poloviny 8 . století či 8./9. století. Výsledky RFA viz tab. 1; ve slitině výrazně zastoupeno olovo.

Ostruha č. 2: V roce 2003 nalezeno v sektoru (čtvrtině) $\mathrm{C}$, tedy v jihozápadní části akropole. Železná ostruha původně pravděpodobně ukončená háčky (dle rozměrů), ty odlomeny. Vyrobena vcelku. Rozměry: d. bodce $32 \mathrm{~mm}$. Obr. 15:2, Kaigl, č. 84. Datováno do 8. století.

Ostruha č. 3: Zlomek ramene železné ostruhy, háček odlomen, rameno na řezu trojúhelníkovitého tvaru s žebírkem, obě hrany jsou zdobeny hustými vseky. Rozměry: š. ramene $8 \mathrm{~mm}$, dochovaná v. oblouku $53 \mathrm{~mm}$. Obr. 15:1. Datováno do druhé poloviny 8. století. RFA: ostruha byla pocínována.

Ostruha č. 4: V roce 2004 nalezeno v jihozápadní části hradiště, v sektoru C. Železná ostruha s háčky, ty z větši části odlomeny, ale dochovala se ohnutí. Bodec masivnější kruhového 

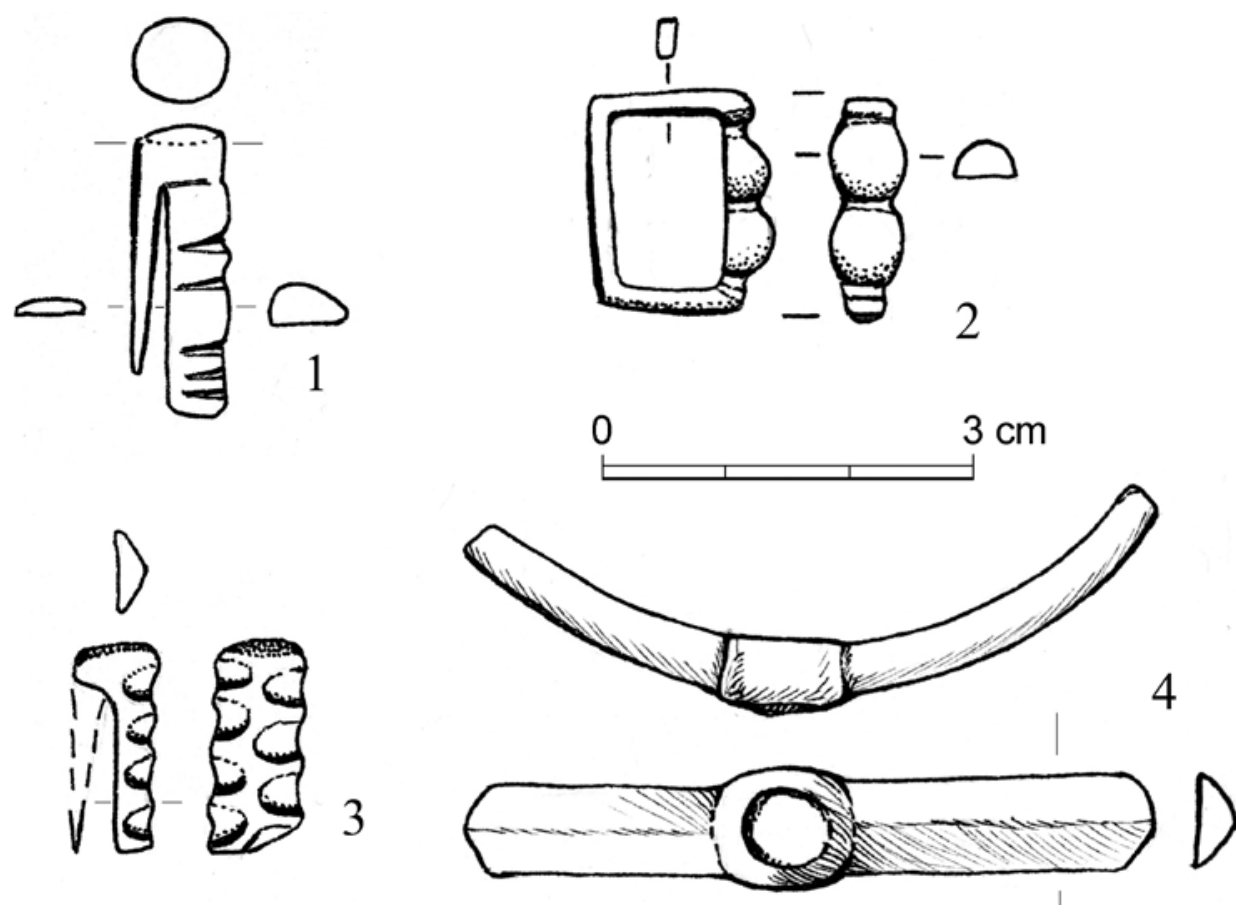

Obr. 10. Tismice, okr. Kolín. Nálezy z roku 2015 - zlomky ostruh a raně karolinská průvlečka k ostruze, bronz. Kresba L. Rasková.

Abb. 10. Tismice, Bezirk Kolín. Funde aus dem Jahr 2015 - Sporenfragmente und frühkarolingische Spornschlaufe, Bronze. Zeichnung L. Rasková.

průřezu ve spodní části. Nešlo určit, zda byl vsazený, či ne, ani nebylo možno kvůli korozi rozpoznat, zda byla zdobená. Rozměry: v. $89 \mathrm{~mm}$, d. bodce $21 \mathrm{~mm}$. Kvalitní kresba není k dispozici, srov. obr. 15:4.

Ostruha č. 5: Bližší poloha nálezu není známa, pouze podle nekvalitní fotografie předpokládáme, že by z hradiště měl pocházet ještě další zlomek železné ostruhy vyrobené vcelku, bez dochovaného ukončení. Jen podle rozměrů a tvaru kuželovitého bodce lze usuzovat, že mohlo jít jak o ostruhu s háčky, tak s očky. Rozměry: přesný rozměr neznámý, v. dochovaného zlomku 82-90 mm, d. bodce 25-30 mm.?

Pozn.: Z hradiště bylo publikováno již pět železných ostruh s háčky (Poulík 1988, obr. 14), z nichž některé byly v 90. letech 20. století rentgenovány v Čechách, a podařilo se doložit tauzovanou výzdobu bodce u čísel 3 a 2 v posledním katalogu (Kouřil ed. 2014, 303); ostruha $\mathrm{s}$ kuželovitým bodcem má drátky z jiného kovu nad bodcem a tři na bodci. Informace však byla zveřejněna jen slovně. Nalezeny byly na plochách B: L VIII, A: S/T VIII a M-o III. Dvě z pěti rentgenovaných ostruh měly bezpečně vsazený bodec pomocí nýtu (ostruha č. sáč. 622/55).

Jedna ostruha s ven vyhnutými háčky byla sekundárně v povelkomoravském objektu a je ze souboru bezpečně nejmladší (Kalčík 2015).

Počet ostruh s háčky tedy dosáhl desítky, vzhledem k minimálně dvěma těžko ověřitelným nálezům ze soukromých sbírek jej nelze stanovit jednoznačně.

Z hradiště pochází také nepublikované nákončí karolinského typu s výběžkem na konci a třemi nýtky v řadě, to mohlo souviset též s jezdectvím nebo podkolenními garniturami. Váže se na tentýž chronologický horizont.

7 Uvedeno pro úplnost. 


\section{Roštín, okr. Kroměř́ž}

Nalezeno roku 2013, ca z Roštína 1 km po zelené značce směrem na Brdo, v místě opravy cesty.

Popis: Bronzová na povrchu pocínovaná litá ostruha s háčky a s kuželovitým bodcem. Rozměry: v. 76 mm. Obr. 15:5. RFA byla provedena v roce 2014 (M. Fikrle) na dvou místech (v místě napojení bodce a na rameni). Ostruha byla odlita z bronzu - s poměrně vysokou příměsí olova. Cínování proběhlo bud' čistým cínem, nebo pravděpodobněji směsí cínu a olova (přítomný bismut olovo doprovází, viz tab. 1).

K lokalitě je třeba podotknout, že z polohy Hradisko pochází nález ozdobné destičky přezky zdobené puncovanými kroužky se středy, která může být datována do stejné doby, tedy do závěru 8. a př́ípadně prvních decennií 9 . století. Paralely má v prostředí pozdní doby avarské (Kouřil 2006, obr. 3).

Počet ostruh s háčky se v př́ípadě Brna-Líšně zvýšil ze sedmi na minimálně deset kusů; kombinací nezdobených železných kusů s tauzovanými a nyní i bronzovým exemplářem se Brno-Líšeň řadí k významným lokalitám srovnatelným s Mikulčicemi a Uherským Hradištěm (Klanica 1986; Poulík 1985, 16, obr. 5, 7, 8; Profantová 1994). Umělé navýšení počtu může připadat v úvahu jen u jednoho kusu, kde byla lokalita označena tzv. z druhé ruky, ne přímo od nálezce.

Roštín rozšířil počet lokalit s nálezy bronzových exemplářů na pět na Moravě. Zcela nové je prokázání techniky pocínování u jednoho zlomku zdobené ostruhy s háčky a u bronzového kusu z Roštína. Jde o dosud nejstarší pocínované ostruhy v České republice, i když u železných kusů tento jev nově zjišt'ujeme také v Čechách.

\section{Analýza ostruh podle materiálu a typu}

\subsection{Bronzové ostruhy}

\subsubsection{Ostruhy s háčky - typ I.1.A, technotyp 1}

V rámci ostruh s háčky představují bronzové ostruhy typu I.1.A, technotypu 1 (viz pozn. 12) luxusní kusy. Jejich počet se od prních nálezů prakticky ztrojnásobil (i bez započtení Skorkova), dnes je k dispozici pět celých nálezů o výšce oblouku B, C podle K. Wachovského (1991) a tř́i zlomky z Tismic. Vzhledem k ne zcela jistému zařazení ostruhy ze Skorkova disponujeme nálezy ze šesti, resp. sedmi lokalit oproti pěti nalezištím z Moravy, včetně nových nálezů z Roštína a zlomku ostruhy z Brna-Lišně (obr. 15). Počet jednotlivých ostruh a zlomků je na Moravě vyšší.

Právě pět ostruh z Čech má výrazné moravské obdoby, ovšem jsou si blízké i mezi sebou. Kombinace plochých vývalků a hustých žebírek (Sobotka-Spyšova) se objevuje např. ve Strakonicích, tam jsou však zdobena celá ramena, či v Uherském Hradišti - na Ostrově sv. Jiří, kde je též zdobena jen horní část ramen. Zdobení jen horního úseku ramen ostruhy je doloženo i z Olomouce-Povelu I (Bláha 1988, obr. 7:1). Kuželovitý bodec, jaký mají ostruhy z Mukova či Senohrab, se vyskytl jak ve Strakonicích (též s vývalky - obr. 4:2, 5; Profantová 1994, obr. 5:1), tak v Uherském Hradišti (Profantová 1994, obr. 6:4 - se 3 vývalky), jakož i jinde na Moravě - např. Roštín (obr. 15:5). Tvarově blízký je i samostatně dochovaný bodec ostruhy z Dolánek-Rubína (Profantová 1994, obr. 3:5). Ostruhy z Mukova a Senohrab mají tedy nejen obdobný bodec, ale i výzdobu ramene nad ním - srov. obr. 4 a 8 (Profantová 2015, fig. 4:3).

Velmi blízkou obdobou ostruhy z Mukova je ostruha s háčky č. 2 z Uherského Hradiště Ostrova sv. Jiří (Poulík 1985, obr. 8:4). S touto ostruhou ji pojí výzdoba nad bodcem i výzdoba bodce, odlomený háček; liší se však tím, že bodec není hráněný - takový má ostruha č. 3 z téže lokality (Poulík 1985, obr. 8:3). Vlastní výzdoba ramene je se svým fázovým posunem zrejmě unikátní. Další obdoby se dají najít ještě v Mikulčicích (např. Profantová 1994, obr. 6:1, 5; Klanica 1986, obr. 28, 33). Celkově známe z Mikulčic minimálně pět celých a nejméně jednou tolik 
zlomků bronzových ostruh (10 ks, srov. Klanica 1986; Kavánová 1998, obr. 5), další mohou být nepublikované. Blíže publikované ostruhy z plochy P 1982-83 na předhradí pocházejí z nejstarší tmavé hlinito-jílovité vrstvy nad podložím, kde vystupovaly spolu s litými ozdobami opasku a keramikou a jsou i na základě stratigrafie datovány do poslední čtvrtiny 8. století (Kavánová 1998, 385). ${ }^{8}$ To je asi nejpřesnější chronologické zařazení s tím, že ani jedna ostruha není kompletní, takže šlo o poškozené kusy, užívaly se nejspíše krátce předtím.

Také K. Wachowski řadí výzdobu uplatněnou na tehdy nových nálezech ostruh do druhé poloviny 8. století (1991, Ryc. 6). Je zajímavé, že nově se zlomek plasticky zdobené bronzové ostruhy s háčkem našel i v žárovém hrobě $782 \mathrm{~b}$ v Groß Strömkendorf - bohužel bez keramiky (Gerds 2015, Abb. 217). Lokalita je však geograficky odlehlá (Meklenbursko). Západním ale všeobecně rozšířeným - prvkem je i zdobení rýžkami či žlábky části ramene nad bodcem (srov. pozdně merovejské ostruhy s vyšším obloukem ramene z Urachu; Bernard a kol. 1991, Abb. 50:11-13). Tuto výzdobu nesou ostruhy z Mukova a Senohrab, náznak i ostruha ze Strakonic. Z moravských nálezů ji má ostruha 594-571/83 z Mikulčic (Kavánová 1998, obr. 5:9, ovšem v katalogu Velká Morava je označena ta samá ostruha č. 390/72, srov. Kouřil 2014, 302).

Zatím je publikováno jen několik ostruh, které mají jednoznačné rozšíření ramene v místě nasazení bodce, nejlépe je sledovatelné u ostruhy ze Senohrab a Mukova a též u některých železných kusů (Sv. Jan pod Skalou). Tento prvek odkazuje na západní typy ostruh.

Pouze z Mikulčic a nově z Brna-Líšně (obr. 15:3) byly zatím publikovány menší zlomky ramen bronzových ostruh (Klanica 1986, obr. 28:1,3,5) tak, jako je to v př́ípadě Tismic. Je možné, že takovéto menší zlomky ostruh sídlištního rázu z jiných lokalit mohly uniknout správné klasifikaci.

Ostruha z Tismic č. 80/014 má vazbu na moravské nálezy i způsobem zdobení (vývalky srov. Roštín obr. 15:5), další zlomek ostruhy nese vzácnou výzdobu bez bližších analogií (nejblíže má k výzdobě ostruhy z Roštína). Lze říci, že alespoň v jednom případě se uplatnil princip výzdoby jen na koncích ramen, jak jej známe z většiny ostatních českých nálezů. Můžeme je datovat do druhé poloviny 8 . až počátku 9. století, tedy do doby, z níž pochází většina kovových nálezů z hradiště (Militký-Profantová-Videman 2013). Datace odpovídá i stratifikovaným nálezům z Mikulčic. Vzhledem k jejich zlomkovitosti se mohly dostat do země o něco později.

Všechny tyto nálezy patří do 8 . století, ${ }^{9} \mathrm{v}$ prŕípadě Uherského Hradiště i Mikulčic do jeho druhé poloviny či poslední čtvrtiny (srov. Profantová 2015, 287). V té době a možná přímo v Uherském Hradišti byla nejspíše vyrobena i ostruha z Mukova. Je však třeba přihlédnout k použití pájky k přiletování háčku - tento postup nebyl nikde jinde prokázán, avšak mohlo jít o opravu. To by ukazovalo na delší dobu užívání ostruhy. Z českých nálezů je užitím hráněného bodce i ramene s trojúhelníkovitým hráněným řezem též blízká ostruha ze Sadské (obr. 4:1; 3b s odlomenými konci háčků; Profantová 1994, obr. 4:1).

Bronzové ostruhy s háčky zahnutými dovnitř se v Čechách vyskytují v obdobném počtu jako na Moravě, zatím však existuje jen jedna lokalita, kde se našlo více kusů, byt' ve zlomcích Tismice, okr. Kolín (obr. 10). Minimálně v tomto př́padě jde i podle jiných nálezů (karolinská průvlečka - obr. 10:2, srov. Gabriel 1981, Abb. 2:5, 6, početná litá kování doby avarské, zlacené karolinské nákončí, stř́íbrná mince Karla Velikého, Ag slitek? - Militký-Profantová-Videman 2013) o centrální lokalitu. Jejich počet je však také ovlivněn záměrným průzkumem s pomocí detektoru kovu provedeným ARÚ AV ČR, Praha, v. v. i.

V dalších př́ípadech může jít o ztrátové exempláře související s komunikacemi (Mukov, Strakonice, Štěpánov). Nejhonosnější zlacená ostruha ze Skorkova bude analyzována v rámci západních importů ostruh.

8 Z této nálezové situace pochází i ostruhy 594-391/72 a 594-571/83, jejichž RFA analýzu předkládáme v tab. 1.

9 I když v poslední souhrnné práci Żaka a Maćkowiak-Kotkowské (1988, Tab. 73) jsou moravské kusy kladeny již i do celého 7. století, zdůvodnění není dostatečné. V Mikulčicích nálezové kontexty několika z nich umožňují datování do 8. století (Profantová 1992 - v souvislosti s avarskou kostěnou industrií; 1994, 62), kontexty z Olomouce pak nejsou publikovány, avšak i tam je pravděpodobnější až století osmé. Ze železných ostruh může k datování snad přispět publikace nálezových okolností ostruh z Tišic (Turek 2001), situace z Toušně ve dvou př́ipadech ukazuje též na 8. století (Profantová-Špaček 2003, obr. 11, 12:2). 


\begin{tabular}{|c|c|c|c|c|c|c|c|c|c|}
\hline Lokalita & č. nál. & $\mathrm{Cu}$ & $\mathrm{Sn}$ & $\mathrm{Zn}$ & $\mathrm{Pb}$ & $\mathrm{Ag}$ & $\mathrm{Sb}$ & $\mathrm{Fe}$ & pozn \\
\hline Brno-Líšeň & č. $1 / \mathrm{NR}$ & 63,4 & 9,6 & 63,4 & 25,2 & 0,4 & 0,3 & & zlomek, č. měř. 15668 \\
\hline \multirow[t]{5}{*}{ Mikulčice } & $594-708 / 66$ & 83,27 & $12 / 12,8$ & $1,6 / 2,8$ & $1,25 / 1,5$ & 1,05 & 0,18 & 0,15 & zlomek \\
\hline & $594-834 / 69$ & 45 & 19 & 0,3 & 13 & 23 & 0,25 & 0,45 & $1 \% \mathrm{Au}$ \\
\hline & $594-834 / 69$ & 44,15 & 18,1 & 0,3 & 14,2 & 18,6 & 0,25 & 0,45 & zlomek, $1 \% \mathrm{Au}$ \\
\hline & $594-836 / 69$ & 85,6 & 9,8 & 1,6 & 0,3 & 0,4 & & & celá \\
\hline & $594-390 / 72$ & 90,28 & 6,25 & 0,27 & 0,3 & 0 & & & $\begin{array}{c}\text { ostruha, bok obsah } \\
1,0 \mathrm{Au}\end{array}$ \\
\hline \multirow[t]{2}{*}{ S.P1982-3 } & $594-391 / 1 / 72$ & 87,63 & 6,5 & 0,9 & 4,3 & 0,4 & 0,12 & 0,15 & \\
\hline & $594-391 / 2 / 72$ & 79,08 & 17,5 & & 0,25 & 1,15 & & & zlomky ostruhy \\
\hline \multirow{4}{*}{$\begin{array}{l}\text { Mikulčice } \\
\text { S.P1982-3 }\end{array}$} & $594-571 / 83$ & 75,27 & 16,4 & 0,3 & 6,4 & 0,48 & 0,2 & 0 & ostruha, krček bodce \\
\hline & $594-578 / 83$ & 34,17 & 16,8 & 2,9 & 45,7 & 0,04 & 0,09 & 0,3 & $\begin{array}{l}\text { zlomek ost. č. měř. } \\
\text { 2898, r. } 1990\end{array}$ \\
\hline & $594-578 / 2 / 83$ & 80,68 & 2,5 & 2,5 & 11,7 & 0,07 & 0 & 2,55 & ostruha? \\
\hline & $594-835 / 6 / 79$ & 85 & 8,8 & 2,6 & 3,1 & 0,43 & 0,2 & & zlomek \\
\hline \multirow[t]{4}{*}{ Mukov } & $\begin{array}{l}\text { ostruha komplet. } \\
\text { strana - střed }\end{array}$ & 56,64 & 18,86 & 0,47 & 21,37 & 0,99 & 0,12 & 1,41 & Bi 0,15 \\
\hline & $\begin{array}{l}\text { komplet. strana, } \\
\text { broušený zdobený } \\
\text { konec }\end{array}$ & 54,98 & 18,92 & 0,71 & 22,78 & 1 & & 1,3 & Bi 0,20 \\
\hline & $\begin{array}{l}\text { nekomplet. strana } \\
\text { drážka s pájkou }\end{array}$ & 28,5 & 15,05 & 0,25 & 52,95 & 1,27 & 0,17 & 1,57 & Bi 0,24 \\
\hline & špička & 48,56 & 26,07 & 0,45 & 21,6 & 1,36 & 0,18 & 1,57 & Bi 0,22 \\
\hline \multirow[t]{2}{*}{ Roštín } & ostruha Roštín 1 & 21 & 59 & $<0,1$ & 13 & 2 & & & Bi 0,2 \\
\hline & ostruha Roštín 2 & 31 & 48 & $<0,1$ & 14 & 2 & & & Bi 0,15 \\
\hline \multirow[t]{2}{*}{ Olomouc } & č. 1 & 85,69 & 9,5 & 1,8 & 2 & 0,77 & 0,09 & 0,15 & \\
\hline & č. 2 & 77,27 & 11,5 & 1,35 & 15,9 & 0,46 & 0,23 & 0,3 & \\
\hline Kováry-Budeč & 23-448a pásková & 82,59 & VIII.65 & 0,22 & VIII.65 & 0,07 & 0,08 & 0,15 & \\
\hline \multirow[t]{5}{*}{ Sadská } & $\begin{array}{l}\text { konec ramene, } \\
\text { očištěno }\end{array}$ & 80,22 & 7,99 & 1,3 & 9,52 & 0,97 & & & \\
\hline & $\begin{array}{l}\text { konec ramene, } \\
\text { očištěno }\end{array}$ & 60,45 & 20,18 & & 15,31 & 2,52 & & 0,49 & Bi 0,27 \\
\hline & výzdoba KP & & & & & & & & \\
\hline & $\begin{array}{l}\text { konec ramene, } \\
\text { očištěno }\end{array}$ & 52,51 & 25,68 & 0,37 & 17,34 & 3,18 & 0,23 & 0,7 & \\
\hline & drážka háček KP & & & & & & & & \\
\hline Sekeřice/Osek & bodec & & $\mathrm{X}$ & & & & & $\mathrm{X}$ & \\
\hline
\end{tabular}

Tab. 1. Rentgenová fluorescenční analýza bronzových ostruh z České republiky. Provedli J. Frána, M. Fikrle (oba ÚJF AV ČR, Řež u Prahy; Mikulčice, Olomouc, Roštín) a D. Perlík (Mukov). Část výsledkủ byla již publikována v Profantová 1992. U č. 594-578/83 je u měření bez další specifikace uvedeno „ostruha“, u dalších měření vznikla nejasnost - co znamená poznámka „kloboučky“ - v publikaci J. Frány a A. Maštalky (1992) mohlo dojít i k chybě; podle rukopisného záznamu z r. 1988 by mohlo jít i o kování s výraznými vývalky či nýtky.

Tab. 1. Röntgenfluoreszenzanalyse der Bronzesporen aus der Tschechischen Republik. Durchgeführt von J. Frána, M. Fikrle (beide Institut für Kernphysik der Akademie der Wissenschaften der Tschechischen Republik, Řež bei Prag; Mikulčice, Olmütz, Roštín) und D. Perlík (Mukov). Ein Teil der Ergebnisse wurde bereits veröffentlicht in Profantová 1992. Bei Nr. 594-578/83 wird bei der Messung ohne weitere Spezifikation die Angabe „Sporn“ gemacht, bei weiteren Messungen könnte die Unklarheit aufkommen, was die Anmerkung „kloboučky“ bedeutet, in der Veröffentlichung von J. Frána und A. Maštalka (1992) könnte auch ein Fehler unterlaufen sein; laut dem handschriftlichen Eintrag aus dem Jahr 1988 könnte es sich um einen Beschlag mit deutlicher Auswalzung bzw. Nieten handeln. 


\begin{tabular}{|c|c|c|c|c|c|c|c|c|c|c|c|c|}
\hline & $\mathrm{Fe}$ & $\mathrm{Ni}$ & $\mathrm{Cu}$ & $\mathrm{Zn}$ & As & $\mathrm{Ag}$ & Sn & $\mathrm{Sb}$ & $\mathrm{Au}$ & $\mathrm{Hg}$ & $\mathrm{Pb}$ & $\mathrm{Bi}$ \\
\hline $\begin{array}{c}\text { Senohraby ostruha A } \\
\text { žlutá koroze }\end{array}$ & 12.IX & $<0,05$ & 33,5 & $<0,2$ & II.70 & I. 38 & 29,3 & 0,24 & $<0,05$ & $<0,05$ & 19,74 & $<0,05$ \\
\hline $\begin{array}{c}\text { Senohraby ostruha } \mathrm{A} \\
\text { trn koroze }\end{array}$ & 0,3 & $<0,05$ & 45,9 & $<0,2$ & II. 40 & I. 53 & 31,46 & 0,23 & $<0,05$ & $<0,05$ & 17,79 & $<0,05$ \\
\hline $\begin{array}{c}\text { Senohraby ostruha A } \\
\text { povrch }\end{array}$ & 1.VII & $<0,05$ & 48,5 & $<0,2$ & II. 30 & I. 31 & 28,7 & 0,19 & $<0,05$ & $<0,05$ & 16,95 & $<0,05$ \\
\hline $\begin{array}{c}\text { Senohraby ostruha A } \\
\text { obrus kov. plátku }\end{array}$ & $<0,2$ & $<0,05$ & 80,9 & $<0,2$ & V.52 & 0,56 & I. 84 & 0,06 & 0,5 & $<0,05$ & X.49 & 0,14 \\
\hline $\begin{array}{l}\text { Senohraby ostruha A } \\
\text { obrus hlavní ćásti }\end{array}$ & $<0,2$ & $<0,05$ & 75,5 & $<0,2$ & $<0,1$ & 0,59 & IX.51 & 0,07 & $<0,05$ & $<0,05$ & XII.22 & $<0,05$ \\
\hline $\begin{array}{l}\text { Senohraby ostruha A } \\
\text { lesklý povrch }\end{array}$ & 1.IV & $<0,05$ & 32,7 & $<0,2$ & III.30 & I. 64 & 36,27 & 0,22 & $<0,05$ & $<0,05$ & 24,13 & $<0,05$ \\
\hline $\begin{array}{l}\text { Senohraby ostruha A } \\
\text { kovový plátek }\end{array}$ & $<0,2$ & $<0,05$ & 78,9 & $<0,2$ & III. 20 & 0,69 & II.98 & 0,05 & 0,6 & $<0,05$ & 13,31 & 0,14 \\
\hline $\begin{array}{c}\text { Senohraby ostruha A } \\
\text { trn obrus }\end{array}$ & $<0,2$ & $<0,05$ & 75,3 & $<0,2$ & $<0,1$ & 0,58 & IX.21 & $<0,05$ & $<0,05$ & $<0,05$ & XII.60 & $<0,05$ \\
\hline $\begin{array}{c}\text { Tismice, oblouk } \\
\text { ostruhy }\end{array}$ & 0 & $<0,2$ & 82 & 8 & $<0,1$ & 0,2 & 4 & 0,1 & & & 3 & \\
\hline
\end{tabular}

Tab. 1b. Podrobný rozbor ostruhy ze Senohrab a z Tismic, sledující i zlacený plech. Provedl M. Fikrle.

Tab. 1b. Detailanalyse des Sporns aus Senohraby und Tismice, mit Einbeziehung von Goldblech. Durchgeführt von M. Fikrle.

\section{Zvláštnosti konkrétního technologického provedení}

Sledování slitin barevných kovů z těchto ostruh nebylo dosud souhrnně vyhodnoceno, i když byly publikovány dílčí výsledky (Frána-Maštalka 1992). K dispozici jsou výsledky ze sedmi až devíti lokalit (včetně páskové ostruhy z Budče), početnější jsou ovšem díky analýze více kusů z Mikulčic nálezy moravské (tab. 1). Uvažovalo se, že se ostruhy s háčky odlévaly spolu s některými bronzovými ozdobami opasku asi v Mikulčicích (největší koncentrace, značná typová jednota apod.), a ještě v Uherském Hradišti na Ostrově Sv. Jiří (nedokončený kus). ${ }^{10}$ V případě Olomouce-Povelu I se sice také našel tyglík, ale situace je nejednoznačná a není plně publikována.

Podle slitiny barevných kovů lze ostruhy rozdělit na tři skupiny (tab. 1, 1b).

1) Ostruhy ze slitiny s vysokým obsahem cínu, či cínované (Roštín, Mikulčice: č. 594-834/69 a nejspíše i 594-391/2/72 - tam je zachycen velký rozdíl v zastoupení cínu - může jít též o cínování, i 594-571/83, srov. tab. 1). V jednom případě z Mikulčic se zvýšeným podílem cínu $(16,27 \%)$ a olova $(17,1 \%)$ je v databázi špatně zapsáno prrírůstkové číslo, i když je jednoznačně zachyceno číslo měření 3804, a že jde o ostruhu s háčky z Mikulčic (měření bylo vyňato z tabulky). U ostruhy z Mukova je obsaženo také výrazné množství cínu a olova - tam lokální koncentraci vysvětlujeme užitím pájky z těchto prvků. Podobně je tomu na koncích ramen i v prrípadě nálezu ze Sadské. Nelze vyloučit ani cínování, ale nejde o situaci jednoznačnou.

Nevysvětlené zůstává množství olova u korodované ostruhy č. 2 z Olomouce, proběhlo totiž jen jedno měření na povrchu, bez měření obrusu. Mohlo jít jak o vysoce olovnatý bronz, tak o nějakou povrchovou úpravu, nebo i důsledek korozní vrstvy.

2) Ostruhy z klasického bronzu, u nějž se obsah cínu pohybuje v rozmezí 5-11/13 \%. Příkladem mohou být ostruha č. 1 z Olomouce nebo z Mikulčic č. 594-390/72, 594-835/69 a 836/69. Z Čech sem patří ostruha č. 1 ze Senohrab.

3) Ostruhy z mosazi s vysokým zastoupením zinku. Sem patří nepochybně ostruha z Tismic s obsahem zinku $8 \%$. Tato skupina je nejméně početná.

Výjimečný je obsah stříbra v jedné ostruze z Mikulčic (č. 594-834/69), ta byla bud' postř́břena, nebo vyrobena z bílého kovu (tab. 1, stříbro 23 \%, cín $19 \%$, olovo 13 \%; srov. Profantová 1992, 
638). I kdyby byl obsah cínu nižší uvnitř ostruhy, pořád jde o mimořádné složení, výskyt olova může ukazovat na speciální úpravu povrchu, stejně jako na užití přetavovaných olovnatých bronzů.

Je zřejmé, že ostruhy se odlévaly na několika místech, v Mikulčicích se objevují kusy s poměrně odlišným složením. To může být dáno jak užíváním přetavovaných slitin, tak záměrným cínováním některých kusů.

V případě nálezů z Čech máme zjištěno několik zatím jedinečných řešení, která neznáme odjinud. Někdy je obtížné rozhodnout, zda šlo o opravy, či nějaký méně běžný výrobní postup. Setkáváme se s těmito př́ípady:

1) první použití pájky $\mathrm{k}$ přiletování odlomeného (?) háčku v př́́padě ostruhy z Mukova (zjištěno na základě RFA),

2) rozštěpení ramene a vsazení háčku z jiného kovu - konkrétně ze zlaceného plechu u ostruhy č. 1 ze Senohrab (obr. 3c),

3) vybrušování vnitřní plochy u háčku v případě nálezu ze Sadské (obr. 3b).

V př́ípadě nálezu ze Senohrab též nebyly odstraněny ploché nálitky uvnitř oblouku ostruhy nad bodcem. Nález též ukazuje, že bronzové kusy byly vysoce ceněny, nebot' byly opravovány. Pak ovšem již nesplňovaly nárok kladený na statutární symbol - ten by měl být bez viditelných oprav a kazů. Možná, že byly opravovány, aby jejich nositel mohl dokončit cestu či výpravu, a pak měly být nahrazeny jiným kvalitním výrobkem.

Každopádně je zatím v literatuře popsáno a detailně zdokumentováno jen málo obdobných zásahů, obvykle jen na mladších kusech (oprava ostruhy z Roztok-Žalova II - HošekOttenwelter 2012, F 27).

\section{2 Železné ostruhy}

\subsubsection{Analýza ostruhys ven vyhnutými háčky - typ I. 2, technotyp 2 a a 3}

Vzácnějším nálezem je ostruha s ven vyhnutými háčky, ty se v našem souboru vyskytly dvakrát: Chlum a Štěpánov (obr. 11). Mají v Čechách jedinou paralelu na hradišti v Toušni (Profantová-Špaček 2003, obr. 12:1). Z této lokality pocházejí i dvě ostruhy s dovnitř ohnutými háčky z kvalitních archeologických situací (vrstva, objekt) datovatelných do 8. století (tíž, obr. 11:8 a 12:2). Ostruhy s ven vyhnutými háčky vycházejí z ostruh doby ř́mskél ${ }^{11}$ a starších úseků existence merovejského období, mohou být importy ze Západu. Dobrým př́íkladem je napřr. raně bavorské pohřebiště Straubing, H. 117-8 (Geisler 1998, Taf. 31:39) či Büraburg u Fritzlaru (Wand 1999, 279, s fotografií), kde je ostruha datovaná do konce 7. století. Dalším př́íkladem je opevněné centrum (s karolinským dvorcem) v Karlburgu am Main, kde se mimo nálezy v anglokarolinském zvěrném stylu (Ettel 2011, Abb. 7:6, 7, 8) našla též v prostoru „villy“ železná ostruha s ven vyhnutými háčky a velmi krátkým bodcem (Ettel 2001, Taf. 60:18, Abb. 5:6). Ostruhy s ven vyhnutými háčky se vyskytly i na Moravě, např. v Mikulčicích (Klanica 1986, obr. 28:7-9), ovšem bez odsazeného bodce. Jsou datovatelné do pokročilého 8. století, nelze vyloučit ani začátek 9. století.

Výzdoba s motivem „X“ pak odkazuje na bronzové ostruhy (srov. obr. 4:1, Sadská) v Čechách, na ramenech železných ostruh je vzácná (Profantová 1994, obr. 5:2), vodorovné rýžky se vyskytly na bronzových i železných ostruhách s dovnitř zahnutými háčky v Čechách (Profantová 1994, obr. 3:1, 8) i na Moravě (Klanica 1986, obr. 28:3, 4, 6 a 29:7). Nejbližší nález na východ od Čech je nezdobená ostruha z Mikulčic, objektu 138, kde se kromě keramiky předvelkomoravského rázu vyskytl jeden nezdobený i prožlabený okraj (Klanica 1995, Abb. 26) mladšího rázu.

11 Proto je problém jednoznačně zařadit dosud nepublikovanou ostruhu z Křnince (vrch Chotuc) s ven vyhnutými háčky a delším bodcem čtvercového řezu. Jsou tam doloženy jak nálezy z doby římské, tak raně středověké. Náš nález může být západním importem, stejně jako místní napodobeninou, každopádně rozhojňuje méně běžnou kategorii ostruh s ven vyhnutými háčky. Pokud by šlo o raně středověký import, může spadat již do poslední třetiny 7. století, napodobeninu bych řadila spíše až do 8. století s tím, že bez průvodních nálezů nelze datování upřesnit. Dvě další ostruhy s ploténkami jsou bezpečně datovatelné do 9 . století (jedna z nich obr. 12:2; Profantová v tisku, Abb. 12:1-3). Ostruhy s dlouhým bodcem a ven vyhnutými háčky se na Západě též vyskytly (Kind 2002), ale to už je jiný chronologický horizont. 
11

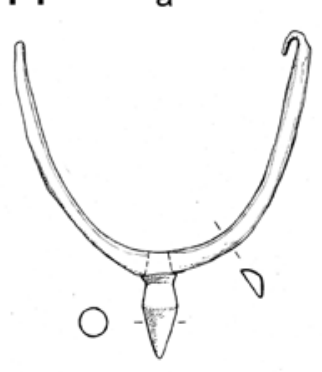

12

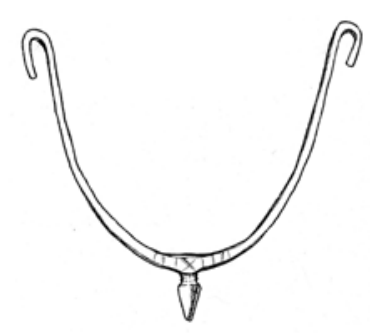

II

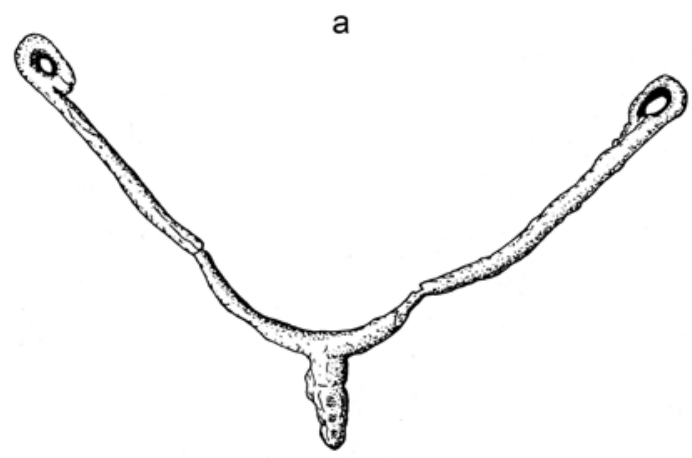

b

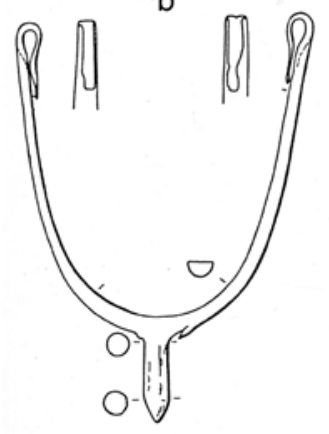

b
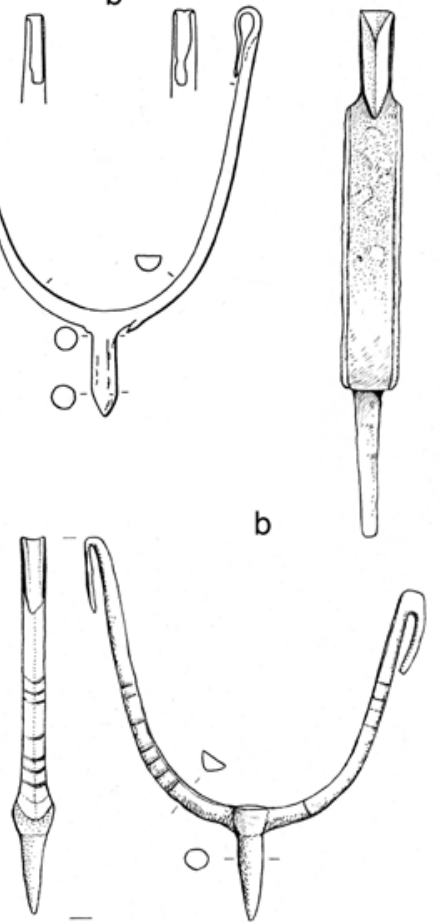

C

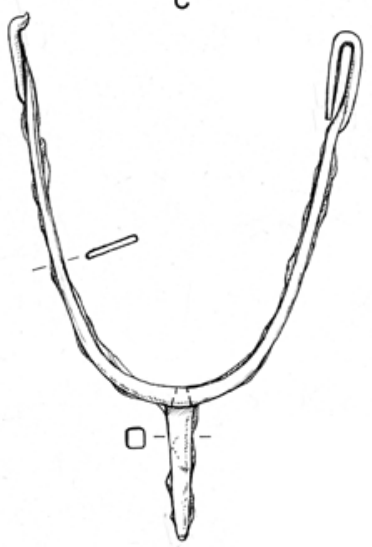

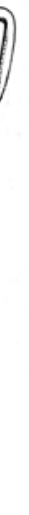

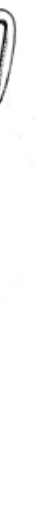
$3 \mathrm{~cm}$

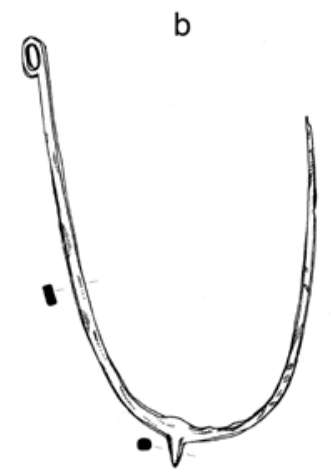

Obr. 11. Hlavní typy ostruh s háčky a očky z Čech. Lokality: I.1.a - Mořinka, č. 1, I.1.b - Benátky u Litomyšle, I.I.c-Sv. Jan pod Skalou, I.2.a - Štepánov, I.2.b - Všestary-Chlum, II.a - Libice n. Cidlinou, II.b - Sekeřice, č. 2. Podle Profantová 2015, fig. 5. Abb. 11. Haupttypen der Haken- und Ösensporen aus Böhmen. Fundstellen: I.1.a - Mořinka, Nr. 1, I.1.b - Benátky u Litomyšle, I.I.c - Sv. Jan pod Skalou, I.2.a - Štepánov, I.2.b - Všestary-Chlum, II.a - Libice n. Cidlinou, II.b - Sekeřice, Nr. 2. Nach Profantová 2015, Fig. 5.

Ostruha z Chlumu může mít souvislost jak s nálezy západními, tak s obdobnými nálezy z Polska (např. Kraków-Nowa Huta, Mogiła, poloha 62 a 62a; Poleski 1992, obr. 3:8, 7), nebo je původu domácího (nově publikovaný o něco mladší (?) nález z Brna-Líšně, nalezený v mladší situaci - Kalčík 2015). Podobné ostruhy se však nověji objevily i v Transylvánii (Cosma et al 2013, Fig. 24:5), ovšem s ploššími rameny. Vzhledem k masivnosti ji nejspíše řadíme do závěru 8. či přelomu 8. a 9. století, na lokalitu se mohla dostat během první poloviny 9. století. Možnost mladšího datování nejnověji podporuje nález s ještě vyšším obloukem ze s. s. j. 13 v Brně-Líšni (Kalčík 2015, obr. 28:14), objevený v kontextu povelkomoravského objektu. 

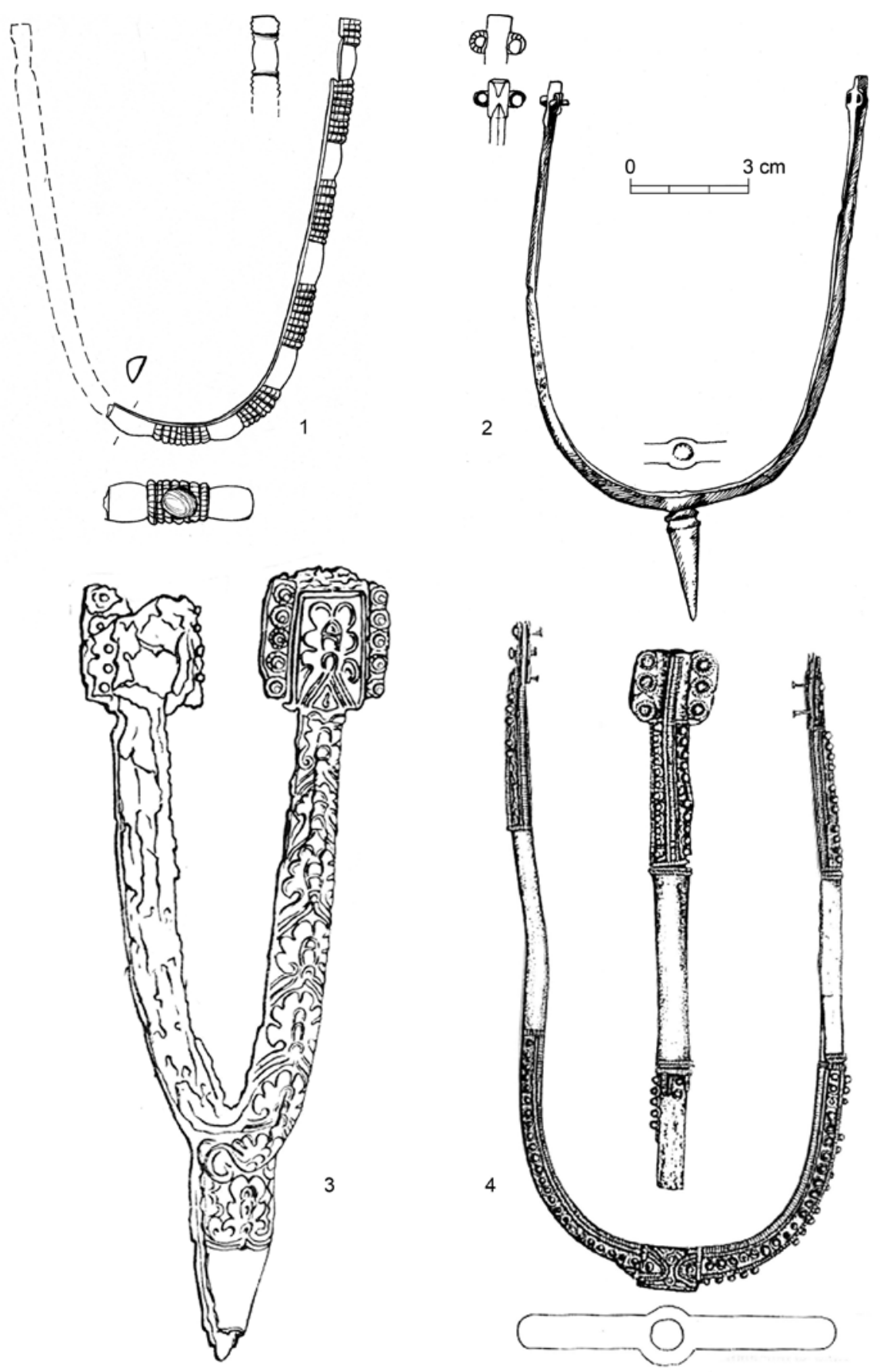

Obr. 12. Importované luxusní ostruhy. 1 - Skorkov, 2 - Křinec, okr. Nymburk, 3 - Kouřim, hrob 120, 4 - Kolín, Součkova cihelna; 1, 2 - zlacený bronz, 3 - plátování zlaceným stř́ibrem. Kresba L. Raslová (1, 2); podle Profantová 2011 (3); podle Šolle 1966 (4).

Abb. 12. Importierte Luxussporen. 1 - Skorkov, 2 - Křinec, Bezirk Nymburk, 3 - Kouřim, Grab 120, 4 - Kolín, Ziegelei Souček; 1, 2 - Goldbronze, 3 - mit vergoldetem Silber plattiert. Zeichnung L. Raslová (1, 2); nach Profantová 2011 (3); nach Šolle 1966 (4). 
Pokud by šlo o západní import, může spadat již do poslední třetiny 7. století, místní napodobeninu bych řadila spíše až do druhé poloviny či poslední třetiny 8. století (doby maximálního rozšíření) s tím, že bez průvodních nálezů nelze datování upřesnit. Přes tuto nejistotu nález rozhojňuje méně běžnou kategorii ostruh s ven vyhnutými háčky.

Pro nástup výroby ostruh s háčky v našem regionu má význam též nález ze Żukowic (Slezsko), polohy 1; ostruha má souvislost s osadou pražského typu, i když se nenašla př́mo v objektu (Parczewski 1989, Taf. 22:1), což ukazuje na 7. století, spíše jeho druhou polovinu či maximálně počátek 8. století. Ostatní nálezy jsou mladší.

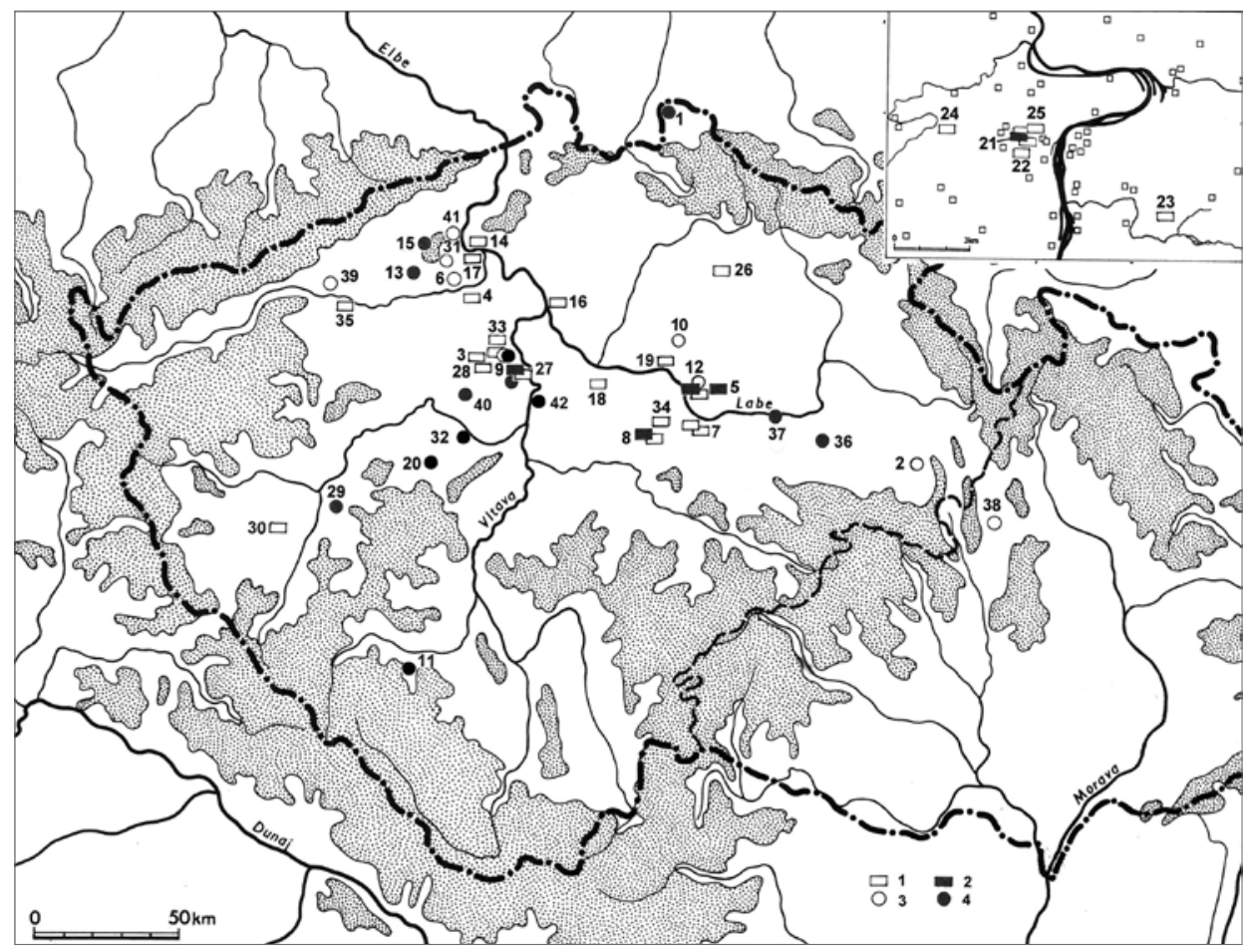

Obr. 13. Nálezy ostruh s ploténkami a ostruh s dlouhým bodcem a ploténkami v Čechách. 1 - hrobový nález; 2 - více hrobů; 3 - hradiště, sídlištní i náhodný nález ostruhy s krátkým bodcem; 4 -sídlištní či náhodný nález ostruhy s dlouhým bodcem. Lokality: 1 - Andělka, 2 - Benátky u Litomyšle, 3 - Brandýsek, 4 - Brníkov, 5 - Kánín, 6 - Klapý, 7 - Kolín, 8 - Kouřim, 9 - Kováry-Budeč, 10 - Křinec-Chotuc, 11 - Libětice, 12 - Libice, 13 - Libčeves, 14 - Litoměřice, 15 - Lukov, 16 - Mělník, 17 - Mlékojedy, 18 - Nehvízdky, 19 - Nymburk, 20 - Otmíče, 21a - Praha-Královská zahrada, 21b - Praha-Lumbeho zahrada, 22 - Praha-Strahov, 22a - Praha-Střešovice, 23 - Praha-Michle, 24 - Praha-Veleslavín, 25 - Praha-M. Horákové, 26 - Prachov, 27 - Roztoky-Žalov a Levý Hradec, 28 - Stehelčeves, 29 - Starý Plzenec, 30 - Stod-Hradec, 31 - Vlastislav, 32 - Tetín-hradiště, 33 - Zákolany, 34 - Žabonosy, 35 - Žatec, 36 - Hlinsko, 37 - Přelouč, 38 - Jevíčko, 39 - Kadaň, 40 Bubovice, okr. Beroun, 41 - Oparno, okr. Litoměřice, 42 - Praha-Vyšehrad. Tmaň-Kotýz - neurčitelný typ - s háčky či ploténkami, stejně jako ztracená ostruha s krátkým bodcem Hradec Králové-Kouty, sídliště - nemapováno. Podle Profantová 2013, Abb. 1, doplněno.

Abb. 13. In Böhmen gemachte Funde von Sporen mit Platten und von Sporen mit langem Dorn. 1 - Grabfund; 2 - mehrere Gräber; 3 - Burgwall, Siedlungs- oder Einzelfund von Exemplaren mit kurzem Dorn; 4 - Siedlungs- oder Einzelfund mit langem Dorn. Fundstellen: 1 - Andělka, 2 - Benátky u Litomyšle, 3 - Brandýsek, 4 - Brníkov, 5 - Kánín, 6 - Klapý, 7 - Kolín, 8 - Kouřim, 9 - Kováry-Budeč, 10 - Křinec-Chotuc, 11 - Libětice, 12 - Libice, 13 - Libčeves, 14 - Litoměřice, 15 - Lukov, 16 - Mělník, 17 - Mlékojedy, 18 - Nehvízdky, 19 - Nymburk, 20 - Otmíče, 21a - Prag-Königsgarten, 21b - Prag-Lumbe-Garten, 22 - Prag-Strahov, 22a - Prag-Střešovice, 23 - Prag-Michle, 24 - Prag-Veleslavín, 25 - Prag - Straße M. Horáková, 26 - Prachov, 27 - Roztoky-Žalov und Levý Hradec, 28 - Stehelčeves, 29 - Starý Plzenec, 30 - Stod-Hradec, 31 - Vlastislav, 32 - Tetín-Burgwall, 33 - Zákolany, 34 - Žabonosy, 35 - Žatec, 36 - Hlinsko, 37 - Přelouč, 38 - Jevíčko, 39 - Kadaň, 40 Bubovice, Bezirk Beroun, 41 - Oparno, Bezirk Litoměřice, 42 - Prag-Vyšehrad. Tmaň-Kotýz - unbestimmbarer Typ - mit Haken bzw. Platten, und auch Hradec Králové-Kouty, Siedlung - nicht erfasst. Nach Profantová 2013, Abb. 1, ergänzt. 

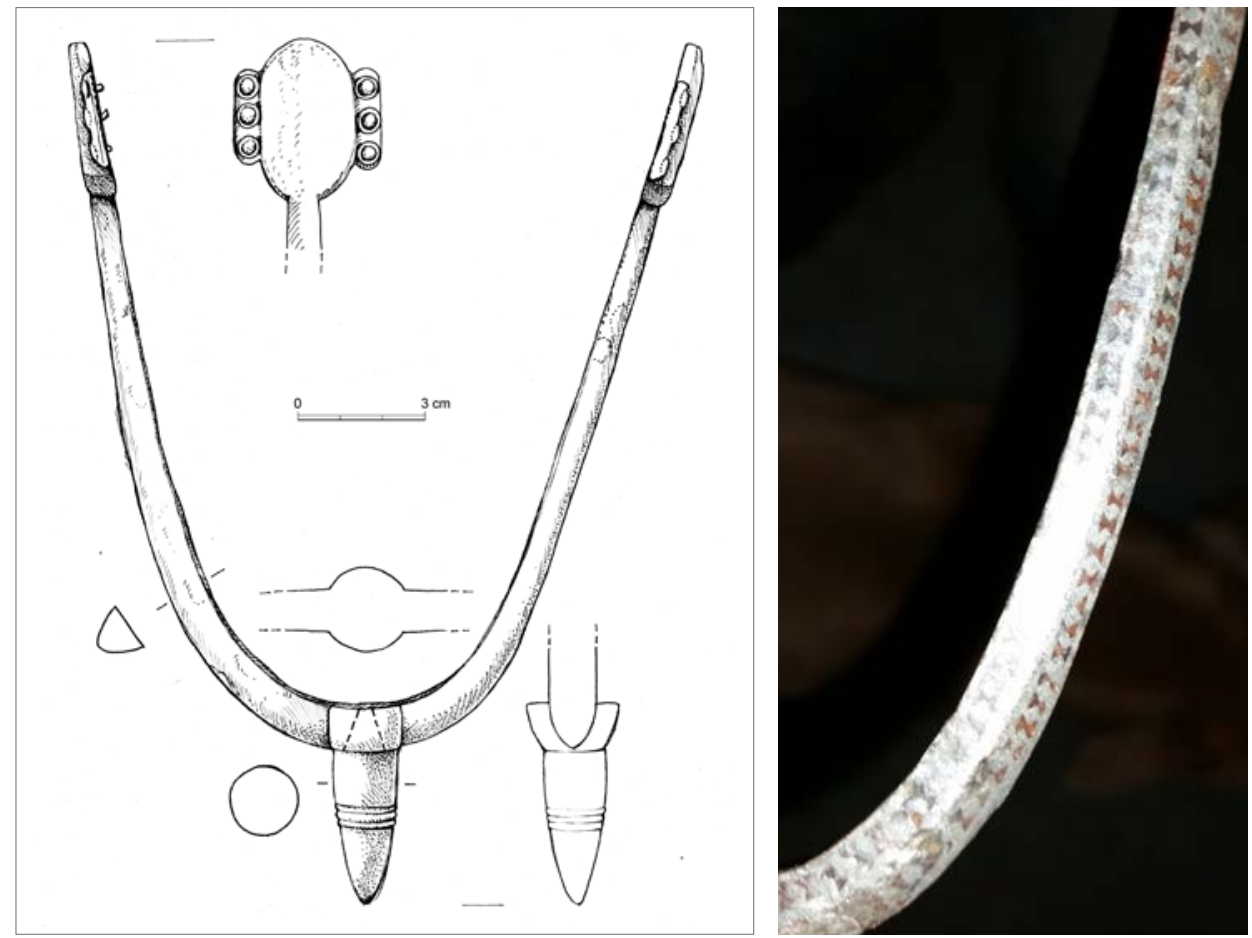

Obr. 14. 1 - Oparno, Opárenské údolí, okr. Litoměřice, 2 - Bubovice, okr. Beroun, 3 - detail výzdoby. Kresba L. Raslová (1); foto N. Profantová (2).

Abb. 14. 1 - Oparno, Oparno-Tal, Bezirk Litoměřice, 2 - Bubovice, Bezirk Beroun, 3 - Verzierungsdetail. Zeichnung L. Raslová (1); Foto N. Profantová (2).

\subsubsection{Analýza železných ostruh s háčky zahnutými dovnitř - typ I.1}

Celkem zveřejňujeme sedm až osm nálezů ostruh s háčky zahnutými dovnitř z pěti nalezišt'. Většina z nich patří typu I.1.A (obr. 11; Profantová 2015, fig. 5) a technotypu T $2 \mathrm{a}^{12}$ (s vsazeným bodcem). Tím se změnil poměr ostruh technotypu T 3 a T 2a (se vsazeným bodcem), obě skupiny jsou zastoupeny víceméně rovnoměrně. Kromě technologie se ostruhy liší především výzdobou a tvarem bodce, nejčastěji se objevuje bodec kuželovitého tvaru, v širším (napřs. Senohraby, č. 2) či užším provedení (Jičíněves, Sv. Jan pod Skalou). Výjimečný je bodec pyramidkového tvaru se žlábkem a oddělenou základnou - ten má jen ostruha č. 1 ze Sekeřic - a bodec s kulovitým prvkem a kuželovitým ukončením pak zdobí i nález č. 2 ze Senohrab (obr. 8). Tyto složitěji členěné bodce mají obdoby např. v Lubomii a Miẹdzyświeći ve Slezsku (např. KouřilGryc 2011, Abb. 10:4, 5, 9). V Lubomii se vyskytuje jednou i žlábkem zaškrcený bodec, jaký má i ostruha z Češova (Profantová 2012, obr. 2:8). Tř́i ostruhy s háčky mají rozšířená ramena v místě vsazení bodce (Sv. Jan pod Skalou, Senohraby, částečně i bronzová ze Senohrab) - to je běžné opět u západních ostruh s očky i jiných typů (např. Walter 2008, Taf. 265:6 - Mengen, hrob 921; Nawroth 2001, Taf. 54:2, 35:8). Setkáme se s ním i u našich importů z 9. století z Křince a Kolína (obr. 12:2,4) nebo u ostruhy z Oparna (obr. 14:1). Chybí většinou u moravských ostruh s háčky i ploténkami. Je však třeba doplnit, že obdobná zdobená ostruha se vyskytla i ve východním Polsku, např. Gródek, a byla řazena do doby mezi 8. stoletím a polovinou 10. století; tyto ostruhy jsou všeobecně dávány do souvislosti s módní vlnou z jihu (tedy z území Moravy, př́íp. dnešního

12 Technotyp představuje třídění ostruh na základě technologických a konstrukčních prvků ostruhy, uživají jej již Żak a Maćkowiak-Kotkowska 1988, nelze však uplatnit na všechny kusy (nutné rtg apod.). Srov. též Profantová 2015, 285. 


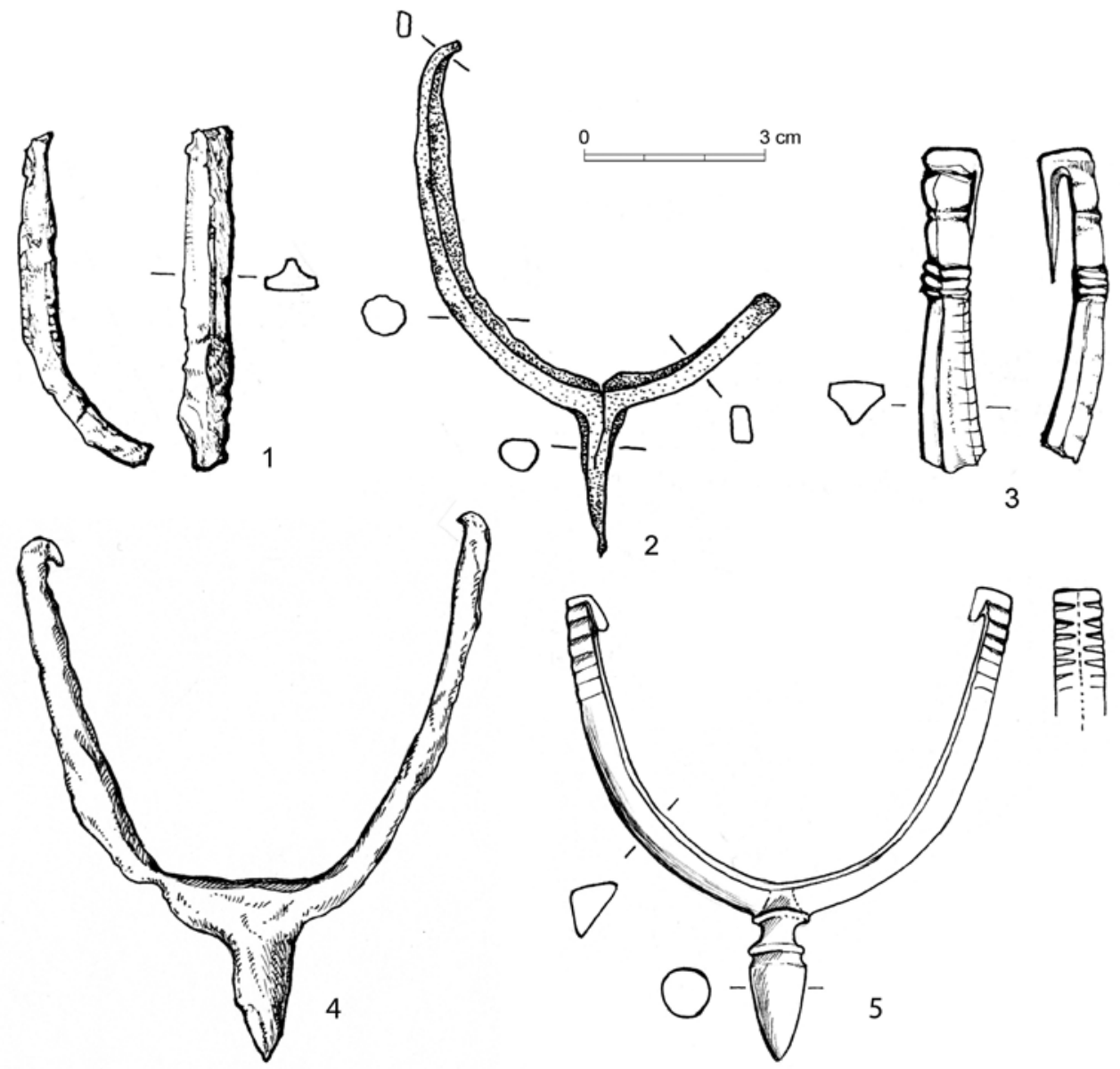

Obr. 15. Brno-Líšeň. 1-4 - bronzová a železné ostruhy, 5 - Roštín. Kresba L. Raslová. Roštín - detail nasazení bodce. Místo zaměření RFA 1.

Abb. 15. Brno-Líšeň. 1-4 - Bronze- und Eisensporen, 5 - Roštín. Zeichnung L. Raslová. Roštín - Detail Dorneinsatz. Anstelle RFA 1.

Slovenska? - Kotowicz 2013, Ryc. 4:7). Vzhledem ke geograficko-chronologickému zařazení se tedy západní vliv v Čechách jeví jako pravděpodobnější.

Oproti třem až čtyřem nezdobeným kusům stojí nálezy č. 1 a 3 ze Sekeřic/Oseka, č. 1 ze Sv. Jana pod Skalou, ostruha z Všestar-Chlumu a ostruha z Češova jako exempláře se zdobenými rameny. Objevují se vstřícné a vodorovné rýžky (Všestary - obr. 11, I.2.2), mírně plastické členění (Sekeřice, obr. 8:1). Výzdoba zaujímá celá ramena (Sekeřice č. 1 - obr. 4:6), konce ramen (Sv. Jan pod Skalou), objevuje se též v místě dotyku ramene s bodcem (napodobení bronzových kusů?).

Kvalitní a bohatě zdobený nový nález ostruhy pochází z výšinného sídliště Sekeřice/Osek, okr. Nymburk. Ostruha je zdobená na ramenech i na silně profilovaném bodci (obr. 4:6; Profantová v tisku, Abb. 11:2). Motiv vstřícných rýžek má analogie především v Mikulčicích (Klanica 1986, obr. 29:6, 33:3) a také na Slovensku (Pobedim - Bialeková 1977, Abb. 4). Důležité je prokázání pocínování povrchu dost korodované ostruhy.

Sekeřice jsou evidentně strategickou lokalitou, odkud pocházejí tři obdobně datovatelné ostruhy a dvě pozdně avarská litá kování opasku, stejně jako raně středověké hroty šípů, hrot kopí a další kovové nálezy, mnohem vzácněji pak keramika staro- až středohradištního rázu (v Muzeu východních Čech v Hradci Králové). 
Kvalitní jsou též ostruha č. 1 z Mořinky a ostruha č. 2 ze Senohrab (obr. 8:6). Odpovídají svým tvarem nálezu z Rubína (Profantová 1994, obr. 3:3, 8) nebo některým nálezům z Moravy (Mikulčice, Brno-Líšeň - Profantová 1994, 64; Klanica 1986). Vsazení bodce se díky novým nálezům jeví jako častější technické řešení, uplatnilo se i u nálezu č. 2 z Mořinky, Senohrab či neúplné ostruhy (č. 3) ze Sekeřic (obr. 8).

Ostruha z Jičíněvsi (obr. 5a) je nejspíše domácím výrobkem 8. století. Paralely má např. v Dolánkách-Rubínu (Bubeník 1988, tab. V; Profantová 1994, obr. 3:4), volnější i jinde v Čechách (např. Kouřim - Profantová 1994, obr. 4:3; Sv. Jan pod Skalou č. 1 - obr. 8:5) a na Moravě (napřr. Klanica 1986, obr. 32:6, 7). Méně běžná je kombinace zesílené objímky pro bodec pod ramenem/či ukončení bodce? a kuželovitého bodce, obdobné zesílení má i ostruha ze Sv. Jana pod Skalou nebo č. 2 ze Senohrab (obr. 8) či některé exempláře západní. Nově je z Jičíněvsi zmíněno naleziště z doby hradištní v poloze pod zámeckým dvorem naproti čp. 7 ve výšce $252-$ $254 \mathrm{~m}$ n. m. Jde o dva střepy kladené do stř̌ední doby hradištní (Ulrychová 2008, 681). Obecně lze nález spojit s širším zázemím hradiště Češov.

Další novější nález železné ostruhy s dovnitř zahnutými háčky pochází z Češova, nález byl učiněn ca $500 \mathrm{~m}$ od valu u jihovýchodního nároží hradiště - na již neopevněné ploše (Vích 2011, 1000, obr. 7:13; Profantová 2012, obr. 2:8; v tisku, Tabelle 3, Abb. 10:8). Jde o ostruhu s jedním koncem ramene odlomeným, vyrobenou vcelku a s plasticky odděleným jehlanovitým bodcem. Datujeme ji do druhé poloviny 8 . až počátku 9. století jen na základě analogií a v souvislosti $\mathrm{s}$ jinými nálezy z hradiště. Původně byla zdobená, výzdoba však byla nešetrnou konzervací zničena (Vích 2011, 1000).

Ostruhy s delšími rameny - jako je exemplář z Benátek u Litomyšle (Profantová 1994, obr. 4:4) či Sv. Jana pod Skalou č. 2 - se užívaly zřejmě minimálně v první až druhé třetině 9. století, to naznačuje jak jiný typ ramen (pásková u posledně zmíněné), tak i některá předatování lokalit s ostruhami s háčky severně našich pohraničních hor (Dulinicz 2001, 100-101). Proporce obou zmíněných ostruh odpovídají lépe ostruze z kostrového hrobu ve Stehelčevsi (Sláma 1977, Abb. 36:9; Profantová 2015, 286) z 9. století a též např. moravským nálezům s plochými rameny a nýty na konci či též s ploténkami, např. z Mikulčic od baziliky (Kavánová 2012, obr. 4-6) či od VI. kostela (Profantová 2003, obr. 45 - též se vsazeným bodcem) nebo z Prušánek, hrob 644 (Klanica 2006, 57-58). Ze západních ostruh stojí poměrně blízko ostruha z Pfahlheimu s vysokými páskovými rameny a očky, vsazovaný bodec se nedochoval (Nawroth 2001, Taf. 54:8), bohužel bez nálezového celku. Ještě prŕíhodnější jsou pozdně merovejské analogie z hrobů v Mengen (Walter 2008, Taf. 153:7, 167, 254) či z Hegau (Theune 1999, Taf. 11:6 s očky). U nálezu z hrobu 573 v Mengen jde vysloveně o vsazení plechového širšího háčku do tyčinkovité části ramene, která přechází v pásek (merovejská ostruha typu III1-B2). Náš případ je další o něco mladší modifikací užívanou v Čechách s jinými typy páskových ostruh, př́ípadně typem s očky (Sekeřice, typ II.b - obr. 11) či ploténkami, ${ }^{13}$ tak s nejstaršími importy ostruh, jako je ostruha č. 2 z Křince (obr. 12:2, viz níže). Může být západním importem nebo reakcí na některé importované kusy. Na tyto chronologické a částečně i technologické souvislosti jsem již stručně upozornila (Profantová 2015, 286).

Ostruhy s háčky zahnutými dovnitř se objevují na celém území Čech (nově Posázaví, intenzivně Poberouní), vyjma užší západní Čechy. V rámci této skupiny (typ I.1) se objevují pravidelně prvky mnohem častější na Západě - vsazování bodce, kruhové rozšíření ramen v místě bodce, výzdoba ramen i bodce, rýžky nad bodcem apod. Ojediněle může jít prŕímo o západní importy (Sv. Jan pod Skalou č. 2? - obr. 8:3).

Nové nálezy neumožnily výrazněji zpřesnit dobu výroby ostruh, snad jen přispěly k posunu horní hranice jejich užívání do konce první třetiny 9. století, u některých, jako je typ I.1.c, až do jeho poloviny. Ovšem rozšírily typovou škálu ostruh s háčky (typ IIb - Všestary-Chlum), k tomu přinesly mladší typ I.1.c ze Sv. Jana pod Skalou (obr. 8:3) a dále i nový typ ostruhy s očky (II.2). Ukázala se také větší variabilita tvaru a zdobení bodce (srov. obr. 4:4, 5, 6; 8:4).

13 Máme tak již téměř kontinuitní výskyt ostruh s háčky směrem k ostruhám s dlouhým bodcem a háčky (např. Nehvízdky - Sláma 1977, Abb. 21:24), i když jejich výskyt je oproti nejstarším typům řídký. 
Ostruhy z Mukova a Štěpánova ukazují na úsek jedné komunikace (obr. 2). Rovněž nálezy z Poberouní (Mořinka, Sv. Jan pod Skalou, Otmíčská Hora?, případně Kotýz - zdobená ostruha bez ukončení, nepublikovaná) souvisejí zřejmě se strategicky významnou komunikací vedoucí na západ do Bavorska (Profantová 2015, 285). To podporují i nálezy nákončí raně karolinského typu např. ze Sv. Jana pod Skalou či Kosoře/Prahy-Zličína (nepublikováno). Nové nálezy ostruh rozhodně rozšírily i spektrum variant $\mathrm{v}$ rámci typu I. Teprve po publikaci početných nových nálezů z Moravy bude možné přesněji vymezit shody a rozdíly výskytu různých typů. Musíme mít však stále na paměti, že v Čechách nebylo zkoumáno v uspokojivém rozsahu žádné ze skupiny nejstarších hradišt' vyjma Klučova, a tedy srovnání se soubory z Mikulčic či Brna-Líšně je poněkud zkreslující.

\subsection{Importované ostruhy s očky či patrněs očky a ploténkami}

Nejstarší importované ostruhy s ploténkami sem byly zařazeny proto, že umožňují lepší datování díky hrobovým celkům, a menší chronologické posuny naznačují, že se v první polovině 9. století na území Čech potkávají různé typy ostruh domácího i cizího původu. Zároveň ostruha z Kolína je původem i kvalitou srovnatelná s ostruhou ze Skorkova.

Mezi importy patři ostruha ze Skorkova, patrně ze Sekeřic, Křince, Kolína a Kouřimi (jako nejmladší typ - obr. 12:3), nejistě pak již rozebraná ze Sv. Jana pod Skalou. Skupina tedy zahrnuje honosnější ostruhy několika typů zhruba od přelomu 8 . a 9. století do 60 . let 9 . století, pouze dvě mladší z ostruh pocházejí z hrobů. Ostruha č. 2 ze Sekeřic má již protáhlejší ramena, háčky ohnuté ven utvářejí očka, typologicky je o něco mladší něž většina ostruh s háčky (Profantová 2015, Fig. 5: II.2; v tisku, Abb. 11) a je importem ze Západu. Nejvhodnější paralelou je ostruha z bohatého hrobu se spathou a udidlem č. 20/1893 z Pfahlheim datovaná do 7. století (Nawroth 2001, Abb. 8, Tab. 39). Podobně je tomu i s nálezem z Francie, tam je železná ostruha obdobného tvaru kladena na konec 7. století, případně do samého počátku 8. století (Fassbinder 1999, IV/135, 260). Ovšem užívaly se i ve století osmém, ale objevují se méně v hrobech. Naše ostruha patří až přelomu 8. a 9. či první polovině 9. století. To podporují další nálezy z lokality, dvě litá kování opasku avarského typu i nepočetná keramika, a neprrímo také fakt, že tento typ chybí v nejstarších kostrových hrobech ze středu 9. století. Železná ostruha z Chodlika (Kotowitz 2013, ryc. 4:5) pak může být napodobeninou podobných kusů.

Zlacená ostruha ze Skorkova, původně se železným bodcem patří k nejhonosnějším nálezům ve střední Evropě (obr. 11:1). Typem se řadí mezi ostruhy raně karolinské, výškou oblouku typu F podle K. Wachowského (1991, ryc. 1). Ta je srovnatelná s výškou kategorie L u ostruh s ploténkami (Wachowski 1986/1987, Abb. 3).

V našem prostředí jediná honosností srovnatelná je taktéž zlacená ostruha z knížecího dvojhrobu v Kolíně, zdobená navíc granulací (obr. 12:4; Lutovský 1996, obr. 4; Košta-Lutovský 2014, tab. 10, v knize i detailní rozbor). Celek je dosti spolehlivě datovaný do střední třetiny 9. století, snad až okolo roku 850. Hrob představuje pohřeb jednoznačně sociálně nejvýše postaveného vládce z 9. století v Čechách - alespoň na základě archeologických pramenů. Sociálně významnější by byl pouze pohřeb realizovaný v kostele - pokud bychom připustili, že alespoň některý z duces pokřtěných roku 845 u křest’anství setrval.

V raně karolinském prostředí jsou takto luxusní též jednotlivé ostruhy, někdy i bez hrobových celků (např. Barsleben, hrob, Pfahlheim-Letten - v lese, nebo Rhein u Mainze, Haithabu Stein 1967, Taf. 65:17, 18, 34:4 a 87:2; Koch 1984; Nawroth 2001, Abb. 86, 198; Schulze-Dörrlamm 2009, Abb. 21:5, 22:6). Tyto zlacené ostruhy s očky mají také zdobená celá ramena a patří většinou do 8 . století, v některých případech je datuje výzdoba odvozená z ornamentů Tassilova kalichu.

Vůbec doposud nejbližšími analogiemi jsou ostruhy z Gojače-Borštu, hrobu 5 (spolu s nákončím s výběžkem; Karo 2012; Robak 2014, tab. 78:7C) a z Gradišče nad Bašljem. Tam byla spolu s průvlečkami, přezkami a stejně zdobenými křížovými kováními a karolinskou luxusní garniturou k závěsu meče s průvlečkou s prodlouženým krčkem nalezena podobná železná os- 
truha pomocí detektoru kovu. Ostruha má dochován bodec zdobený drátky/vývalky, výzdoba ramen záměrně chybí ve střední části (Karo 2012a; Milošević 2013, fig. 105). Garnitura nalezená s ostruhou pochází již z poslední čtvrtiny 8 . až první poloviny 9 . století. Ovšem jedná se o datování bez stratigrafie a bližšího kontextu.

Ostruha ze Skorkova představuje ztrátový artefakt, ale ukazuje pohyb vysoce postavených osob v českém Polabí v první polovině 9. století, stejně jako karolinská mince z ne příliš vzdáleného Kostelního Hlavna (Videman-Profantová 2014) či jiné luxusní karolinské artefakty (např. zlacené nákončí zdobené zvěrným stylem Tassilova kalichu z Češova či trochu mladší průvlečka s prodlouženým krčkem z Hradska u Mšena apod. - např. Profantová 1999; 2011, obr. 12:1).

Základním materiálem této ostruhy je bronz (66 \% měd' a $14-15 \%$ cín) s významnou příměsí zinku, arsenu a olova tvořící sumárně přibližně $9 \%$ slitiny. Zlacení ostruhy bylo provedeno amalgamací (poměr zlato : rtut' je ca 6,5 : 1, RFA proběhla v ÚJF AV ČR v Řeži u Prahy, M. Fikrle). Složení odpovídá raně středověkým bronzům, pro něž je typická určitá příměs zinku a olova (srov. tab. 1). Zlacení amalgamací se běžně užívá v 8. i 9. století. Vzhledem k tomu, že jde o import, nezařazuji výsledky měření do tabulky.

Další jen bronzová pásková ostruha - původně nejspíše též s železným bodcem - se našla v druhotném umístění na akropoli Budče poblíž rotundy sv. Petra (Profantová 1994, obr. 9:5). Dobou výroby v první a druhé třetině 9 . století je dost blízká výše uvedené, avšak mohla být užívána delší dobu (to ukazuje mladší nálezový kontext), a je též bez uchovaného ukončení (asi 2 nýtky). Honosností však srovnatelná není a mohla být jen napodobeninou západních kusů.

Železná ostruha z Křince s filigránovými věnečky okolo dvou nýtků upevněných kolmo na rameno ostruhy (s ním vytvářejí kříž) a s rameny ve tvaru U téměř trojúhelníkovými na řezu je též importem (obr. 11:2; Profantová 2015, 288). Podařilo se prokázat částečné cínování povrchu. Nejbližší paralela k této ostruze (č. 2) se našla v Chotěbuzi-Podoboře, pochází ze sondy 42 (Kouřil 2007, obr. 4 - i v této práci je zdůrazněn řídký výskyt obdobných kusů). Je tu jedna odlišnost - u našeho exempláře chybí nýt na konci ramene. Zlomek obdobné ploténky pochází z Gilówa ve Slezsku (Jaworski 2005, obr. 145:g) a je kladen do souvislosti s velkomoravskými vlivy. Další podobný nález známe z Hemmabergu v Korutanech, tam je křížek na konci ramen zdůrazněný lištami, a jde o franský import druhé poloviny 8. až první třetiny 9. století (Eichert 2012, 95, Abb. 119). Právě filigránové věnečky a zdobení konců ramen a celková gracilita nálezu ukazují v př́ípadě Křince spíše na cizí provenienci; tento závěr může podpořit i částečné cínování. Datovat ji můžeme do 9. století, spíše prvé poloviny. I když oproti Skorkovu, Kolínu či stř́ibrem plátované ostruze s rytou rostlinnou výzdobou z Kouřimi, hrobu 120 (obr. 11:3), ${ }^{14}$ jde o běžnější kus, ukazuje spolu s dalšími nálezy na mnohem užší kontakty s franskou říší. Importem mohla být také velikostně zcela předimenzovaná ostruha z Oparna (Opárenské údolí u Litoměřic) se dvěma trojicemi svisle umístěných nýtků na každé straně ploténky a vsazeným trojicí vývalků zdobeným bodcem. Ramena má v místě bodce polokruhově rozšířená (obr. 14:1). Nejbližší paralely má v Nymburce-Zálabí a Kouřimi, hrobě 55, v obou případech se vsazeným bodcem a stopami tauzie (Profantová 1994, obr. 7, 8), ovšem bez onoho kruhového rozšíření v místě upevnění bodce. Z bližšího západního prostředí lze jen upozornit na Orsfriehof Weisman-West, hrob 55, případně 79, odkud pocházejí obdobné ostruhy z hrobových celků datovaných ještě do 8. století (Schwarz 1984, Abb. 68, 69, 71).

Rozšíření v místě nasazení bodce je dobře viditelné např. u ostruhy ze Scharstorfu (Gabriel 1988, Abb. 3:1), ale ta má na ploténce stř̌edové zesílení. Obdobné ostruhy se však vyskytly i na Moravě - s viditelným rozšířením v místě bodce pak ve Starém Městě a v Mikulčicích (Kouřil 2005, zejm. Abb. 9 a 14) a patří k nejstarším hrobovým celkům z první poloviny 9 . století. Naše ostruha se vymyká hlavně kombinací masivnosti s absencí výzdoby ramen. Ve všech hrobech působily tyto ostruhy, někdy označované jako typ Biskupija-Crkvina, ${ }^{15}$ jako statutární symbol,

14 Ostruha z Kouřimi má některá specifika, má relativně blízko i k nálezům Biskupija-Crkvina u Kninu, z nichž mnohé jsou také importy z karolinského prostředí. Ke stratigrafii na lokalitě, a tedy i k chronologii hrobů s ostruhami nově Petrinec-Jurčević 2015, zvl. 353-356. Lépe doloženo datování okolo roku 800 (nový hrob 125), v sarkofágu s motivem hypokampů mohl být pohřben kníže Borna mezi lety 820 a 830 . 15 Viz pozn. 14. 
takže i nález z Oparna jednak zvyšuje koncentraci militarií v okolí Litoměřic a jednak patří k nejstarším v rámci této koncentrace (naposledy Meduna 2009). Představuje první nález tohoto typu v severozápadních Čechách.

Tuto část lze uzavřít tím, že nejhonosnější ostruhy z Čech byly importované západní kusy a nejpozději v polovině 9 . století se již objevují v hrobech příslušníků elity, snad označené písemnými prameny jako duces (srov. Boháčová-Profantová 2014; Košta-Lutovský 2014). Nutno však dodat, že elitních hrobů s nejstarším typem ostruh s ploténkami není mnoho (ca sedm až osm celků - srov. obr. 13, hlavně 7, 8, 19, 21?,28) a že se koncentrují jen ve středních Čechách, což je ovšem silně ovlivněno stavem výzkumu.

\section{Závěr}

Nové nálezy ostruh nepocházejí z hrobů, ale z různých výšinných sídlišst’ a hradišt' (obr. 9), často souvisejí s průběhem cest (Profantová 2015). Nelze proto vždy odlišit, zda je nosil cizí či domácí jezdec-bojovník. Každopádně však ukazují odstupňování od prostého funkčního kusu (St. Kouřim - ostruha s háčky, Jičíněves, Klučov, Otmíče) přes bohatě zdobené železné cínované i necínované kusy (Sekeřice, Lázně Toušeň - č. 2, Rubín, Všestary-Chlum - obr. 11:I.2.b) až po luxusní bronzové, či dokonce zlacené ostruhy (Skorkov - obr. 12:1, Kolín - obr. 12:4, Kouřim - obr. 12:3). Intenzita jejich používání (a následného ztracení či zahození) byla srovnatelná ve druhé polovině 8 . a po celé 9 . století. Pokud posuzujeme nepočetnou kolekci z hrobů 9 . století, jde většinou o železné kusy zdobené plasticky (Stehelčeves) či cínovou, prŕípadně stříbrnou tauzií (Mělník, Nymburk-Zálabí, St. Kouřim, hrob 55 - srov. Profantová 1994, obr. 8, 10), v nejbohatších hrobech pak jde o zlacené kusy či ostruhy plátované stř́ibrem (Kolín, Kouřim, hrob 120 - obr. 12).

Velký počet nálezů především ostruh s háčky na různých výšinných polohách či v zázemí hradišt' (např. Vesec, hradiště či výšinné sídliště Poráň - Čtverák-Lutovský a kol. 2004, 338-339; Profantová-Waldhauser 2007 - v širší oblasti nálezu u Sobotky, č. 1, na obr. 1) dokresluje informace písemných pramenů o častějším pohybu vojsk na území Čech na konci 8. a počátku 9. století. ${ }^{16}$

O těchto pohybech svědčí právě ztrátové nálezy ostruh i zbraní (nejčastěji sekery, příp. kopí, hroty šípů), ovšem většina zbraní neumožňuje stanovit kratší interval jejich výskytu.

Počet hrobových nálezů ostruh je největší v poslední třetině 9. a první polovině 10 . století, kdy plnily funkci statutárního označení př́slušníka elity (obr. 13). Z této doby disponujeme také větším počtem zkoumaných nekropolí, byt' jen minimum bylo prozkoumáno kompletně (Kouřim u Libuše, Praha-Lumbeho zahrada). Ostruhy plnily svoji symbolickou roli nejprve spolu se zbraněmi, v průběhu 10. století pak již samostatně (např. Kouřim, Libice, Roztoky-Žalov I).

Přestože na českých pohřebištích je doložen výrazně menší počet mužů - jezdců oproti Moravě 9. století, byla armáda plně schopna bojovat s franskou říší (např̀. v letech 846-849) a později i proti Moravanům (r. 898; srov. Boháčová-Profantová 2014, 144). Proto rozdíl v četnosti ukládání ostruh do hrobu odráží spíše jiný důraz na označování statutu v pohřebním ritu a zejména kratší úsek spíše „nejistého“ postavení elity, kdy bylo nejvíce potřeba nabytý či očekávaný status demonstrovat.

Proto i přes nedostatečný stav výzkumu pohřebišt' (zejména pro 9. století) spíše předpokládám, že jde o trochu odlišné vnímání společenské a symbolické role atributů moci (tedy včetně ostruh) v již poměrně stabilizované společnosti. Můžeme očekávat i odlišné četnosti jejich výskytu v různých regionech Čech v souvislosti s různě rychlými změnami pohřebního ritu. Již nyní je zřetelné, že širší Kolínsko/Kouřimsko má o něco blíže k Moravě - a to včetně větší koncentrace hrobů s ostruhami (Kouřim -8 hrobů, Libicko - 12 hrobů) - než Pražsko včetně Levého Hradce (ca 5 hrobů v Praze-Lumbeho zahradě, po jednom hrobě na dalších 4 pohřebištích v zázemí Hradu a 5 hrobů z Roztok-Žalova I, II), byt' statisticky jde o malé počty. To však neznamená, že by mělo Kolínsko větší politickou moc. Spíše tam nastoupilo kostrové pohřbívání

16 Písemně je doložen pohyb Karlova vojska k r. 791 a jeho syna v letech 805, 806. Jde o informace Chronicon Moissiacense a Análů fuldských (Profantová 2014, 62). 
nejdříve (Kolín, Kouřim, H 55, H 120, Nymburk - hroby z 1. poloviny či poloviny 9. století) což vyplývá i z nového rozboru karolinských kování garnitur k meči Z. Robaka (2014, Tab. 1), a máme k dispozici více (byt' v malých absolutních číslech) hrobů nejvyšší elity. Luxusní ostruhy ze stejné doby - tedy z první poloviny 9. století - ze středních Čech známe, ale zatím většinou bez hrobového kontextu (Budeč-akropole, Skorkov, Křinec - obr. 12, Oparno na Litoměřicku obr. 14). Výjimečnost/nepočetnost nejstarších bohatých hrobů v užších středních Čechách může souviset s žitou kontinuitou nejvýznamnějšího centra - mnoho situací v Praze je definitivně zničeno. Význam Pražské kotliny podporuje i zjištění, že jediný dětský hrob s ostruhami s krátkým bodcem pochází právě z Prahy-Lumbeho zahrady (hrob 65 - Frolík-Smetánka 2014, 122-123 popsány však jako s dlouhým bodcem) a že se zde realizovaly první knížecí pohřby v kostele (Hrad, P. Marie, bazilika sv. Jiří, rotunda sv. Víta), a tedy i bez atributů, jako jsou ostruhy a meč (Spytihněv $\dagger 915$, Vratislav $\uparrow 921$, Václav $\uparrow 935)$.

Přesto je třeba naznačené regionální rozdíly dále sledovat a pokoušet se cíleněji (snad s využitím menších badatelských výzkumů) zapojit do srovnání ještě další region z těch, o nichž z hlediska nejstarších bojovnických hrobů zatím nic nevíme (jižní, západní Čechy).

\section{Literatura}

BENKOVÁ, I.-ČTVERÁK, V., 1998: Areál ve sv. Janu pod Skalou? (okr. Beroun), ASČ 2, 115-144.

BERNARD, H. a kol., 1991: Bernard, H.-Böhner, K.-Holliger, Chr.-Koch, U.-Knaut, M.-Oeftinger, C.-Pauli, J.-Roth-Rubi, K.-Schiek, S.-Spors-Gröger, S.-Wagner, E., Der Runde Berg Urach. Führer zu archäologischen Denkmälern in Baden-Württemberg B. 14. Stuttgart.

BIALEKOVÁ, D., 1977: Sporen von slawischen Fundplätzen, SlArch XXV, 103-160.

BLÁHA, J., 1988: Předběžná zpráva o objevení předvelkomoravského ústředí v Olomouci - Das vorgroßmährische Zentrum in Olomouc, Vorbericht, AH 13, 155-170.

BOHÁČOVÁ, I.-PROFANTOVÁ, N., 2014: Čechy a Velká Morava - Svědectví archeologie. In: Velká Morava a počátky křestanství (Kouřil, P., ed.), 134-144. Brno.

BUBENÍK, J., 1988: Slovanské osídlení středního Poohří - Die slawische Besiedlung im Einzugsgebiet der mittleren Ohře. I. Praha.

COSMA, C. a kol., 2013: Cosma, C.-Dobos, A.-Rustoiu, G. T.-Rustoiu, A.-Oargă, O., Războinici în Transilvania din epoca Avară. Cluj-Napoca.

ČTVERÁK, V.-LUTOVSKÝ, M.-SLABINA, M.-SMEJTEK, L., 2004: Encyklopedie hradišt’ v Čechách. Praha.

DULINICZ, M., 2001: Ksztaltovanie şie Slowianszczyzny Pólnocno-zachodniej. Studium archologiczne. Warszawa.

EICHERT, S., 2012: Frühmittelalterliche Strukturen im Ostalpenraum. Studien zu Geschichte und Archäologie Karantaniens. Klagenfurt am Wörtherse.

ETTEL, P., 2001: Karlburg-Rosstal-Oberammerthal. Studien zum frühmittelalterlichen Burgenbau in Nordbayern. Frühgeschichtliche und provinzalrömische Archäol. Materialien und Forschungen 5. Rahden/ Westfahlen.

- 2011: Der Frühmittelalterliche Zentralort Karlburg am Main mit Königshof, Marienkloster und zwei Burgen in karolingish-ottonischer Zeit. In: Frühgeschichtliche Zentralorte in Mitteleuropa. Studien zur Archäologie Europas 14 (Macháček, J.-Ungerman, Š., edd.), 459-478. Bonn.

FASSBINDER, S., 1999: IV:136. Sporn. In: 799. Kunst und Kultur der Karolingerzeit. Karolingerzeit Karl der Grosse und Papst Leo III. in Paderborn (Stiegemann, Ch.-Wemhoff, M., edd.), 260. Paderborn - Mainz.

FRÁNA, J.-MAŠTALKA, A., 1992: Röntgenfluoreszenzanalyse von frühmittelalterlichen Bronzen aus Böhmen und Mähren. In: Daim, F., Awarenforschungen II, 779-801. Wien.

FROLÍK, J.-SMETÁNKA, Z., 2014: Pohřebiště v Lumbeho zahradě na Pražském hradě I. Katalog. Castrum Pragense 12. Praha.

GABRIEL, I., 1981: Karolingische Reitersporen und andere Funde aus dem Gräberfeld von Bendorf, kr. Rendburg-Eckernförrde, OFFA 38, 245-258.

- 1988: Hof- und Sakralkultur sowie Gebrauchs- und Handelsgut im Spiegel der Kleinfunde von Starigard/ Oldenburg, Bericht RGK, 103-291.

GEISLER, H., 1998: Das frühbaierische Gräberfeld Straubing-Bajuwarenstrasse I. Internat Archäol. 30. Rahden. 
GERDS, M., 2015: Das Gräberfeld des frühmittelalterlichen Seehandelsplatzes von Groß Strömkendorf, Lkr. Nordwestmecklenburg. Forschungen zu Groß Strömkendorf. B. 2. Wiesbaden.

HOŠEK, J.-OTTENWELTER, E., 2012: Metalograficko-restaurátorský průzkum železných předmětů z žalovských pohřebišt'. In: Tomková, K. a kol., Levý Hradec v zrcadle archeologických výzkumů. Pohřebiště. Díl I., 282-289. Praha.

CHMIELOWIEC, S.-KAŠPAR, V., 2011: Kilka uwag o żelaznym grocie włóczni z okolic Zlenic. In: Non sensistis gladios. Studia ofiarowane Marianowi Głoskowi w 70. rocznicę urodzin (Ławrynowicz, O.Maik, J.-Nowakowski, P. A., edd.), 87-99. Łódź.

JAWORSKI, K., 2005: Grody w Sudetach (VIII-X w.). Wrocław.

KALČÍK, L., 2015: Povelkomoravské osídlení hradiska Staré Zámky u Líšně, PV 56, 127-200.

KARO, Š., 2012: Zgodnjekarolinške najdbe s slovenskih najdišč. In: Emona med Akvilejo in Panonijo Emona between Aquileia and Pannonia (Lazar, I.-Županek, B., edd.), 447-458. Koper.

- 2012a: Oprema jahača i konja s Gradišča nad Bašljem (Slovenija) - Military and horse equipment from Gradišče above Bašelj (Slovenia). In: Dani Stjepana Gunjače 2. Zbornik radova (Šeparović, T., ed.), 297-315. Split.

KAVÁNOVÁ, B., 1976: Slovanské ostruhy na území Československa - Slawische Sporen auf dem Gebiet der Tschechoslowakei. Studie AÚ ČSAV v Brně IV/3. Praha.

- 1998: Bronzová zoomorfní faléra z Mikulčic a její zařazení ve stratigrafii sídliště na předhradí, Pravěk NŘ 7/1997, 373-388.

- 2012: Poznámka k relativní chronologii ostruh s páskovými rameny. In: Mezi raným a vrcholným středověkem. Pavlu Kouřilovi k 60. narozeninám (Doležel, J.-Wihoda, M., edd.), 169-183. Brno.

KIND, T., 2002: Archäologische Funde von Teilen der Reitausrüstung aus Europa und ihr Beitrag zur Kultur- und Sozialgeschichte der Ottonenzeit. In: Europa im 10. Jahrhundert. Archäologie einer Aufbruchszeit (Henning, J., Hrsg.), 283-299. Mainz.

KLANICA, Z., 1986: Počátky slovanského osídlení našich zemí - Die Anfänge der slawischen Besiedlung unserer Länder. Praha.

- 1995: Zur Periodisierung vorgroßmährischer Funde aus Mikulčice. In: Studien zum Burgwall von Mikulčice. Spisy Archeologického Ústavu AV ČR Brno 2, Bd. I (Daim, F.-Poláček, L., edd.), 379-469. Brno.

- 2006: Nechvalín, Prušánky. Čtyři slovanská pohřebiště. Brno.

KOCH, U., 1984: Der Runde Berg bei Urach. Band V. Teil 1. Die Metallfunde der frühgeschichtlichen Perioden aus den Plangrabungen 1967-1981. Heidelberg.

KOŠTA, J.-LUTOVSKÝ, M., 2014: Raně středověký knížecí hrob z Kolína - Early medieval princely burial from Kolín. Fontés Archeologici Pragenses 41. Praha.

KOTOWICZ, P. N., 2013: Problematyka badań bronioznawczych nad wczesnośredniowiecznym uzbrojeniem Lubelszczyzny, Materiały i Sprawodzania Rzeszowskiego Ośrodka Archeologicznego XXXIV, $51-72$.

KOUŘIL, P., 2005: Frühmittelalterliche Kriegergräber mit Flügellanzen und Sporen des Typs Biskupija-Crkvina auf mährischen Nekropolen. In: Die frühmittelalterliche Elite den Völkern des östlichen Mitteleuropas mit einem speziellen Blick auf die großmährische Problematik, Materialien der internationalen Fachkonferenz (Kouřil, P., ed.), 67-100. Brno.

- 2006: Lité bronzové kování z Roštína na Kroměřížsku. In: Aevum Medium. Zborník na počest’ J. Hošša (Zábojník, J., ed.), 57-60. Bratislava.

- 2007: Jezdecká elita na hradisku v Chotěbuzi, Těšínsko 50, 5-8.

KOUŘIL, P., ed., 2014: Velká Morava a počátky křest’anství. Brno.

KOUŘIL, P.-GRYC, J., 2011: Der Burgwall in Chotěbuz-Podobora und seine Stellung in der Siedlungstruktur des oberen Odergebietes vom 8. bis zum 9./10. Jahrhundert. In: Frühgeschichtliche Zentralorte in Mitteleuropa. Studien zur Archäologie Europas 14 (Macháček, J.-Ungerman, Š., edd.), 217-243. Bonn.

LUTOVSKÝ, M., 1996: Kolínský knížecí hrob: ad fontes - Fürstengrab von Kolín: ad fontes, SbNM XLVIII, 37-76.

MĚříNSKÝ, Z., 2014: Staré zámky v Brně-Líšni. In: Velká Morava a počátky křest’anství (Kouřil, P., ed.), 188-195. Brno.

MEDUNA, P., 2009: K počátkům Litoměřic - The onset of the Litoměřice. In: Litoměřická kapitula. 950 let od založení (Hrubá, M., ed.), 23-32. Ústí nad Labem.

MILITKÝ, J.-PROFANTOVÁ, N.-VIDEMAN, J., 2013: Pozdně římské mince a denár Karla Velikého (768-814) z areálu hradiště Tismice, Numismatický sborník 27, 35-46.

MILOŠEVIĆ, A., 2013: Tragovi starih vhjerovanija u kršćanstvu ranog srednjeg vijeka. Studia mediterranea archaeologica 6. Dubrovnik

NAWROTH, M., 2001: Das Gräberfeld von Pfahlheim und Reitzubehör der Merowingerzeit. Nürnberg. 
PARCZEWSKI, M., 1989: Żukowice pod Głogowem w zaraniu średniowiecza - Żukowice pod Głogowem am Anfangdes Mittelalters. Głogów.

PETRINEC, M.-JURČEVIĆ, A., 2015: Insights into Chronology of the Site from late 8th to 15th century. In: Sword, Crowns, Censers and Books. Francia Media - Cradles of European culture (Vicelja-Makijašic, M., ed.), 327-372. Rijeka.

POLESKI, J., 1992: Podstawy i metody datowania okresu wczesnośredniowiecznego w Małopolsce. Prace Archeologiczne UJ 52. Kraków.

POULÍK, J., 1985: Svědectví výzkumů a pramenů archeologických o Velké Moravě. In: Velká Morava a počátky československé státnosti (Poulík, J.-Chropovský, B., edd.), 9-80. Praha - Bratislava.

- 1988: K otázce vzniku předvelkomoravských hradišt' - Zur Frage der Entstehung vorgroßmährischer Burgwälle, SlArch XXXVI, 189-216.

PROFANTOVÁ, N., 1992: Awarische Funde aus den Gebieten nördlich der awarischen Siedlungsgrenzen. In: Awarenforschungen II (Daim, F., ed.), 605-778. Wien.

- 1994: K nálezům ostruh z konce 7.-9. stol. v Čechách - Spurs from the 7th-9th century in Bohemia. In: PA 85 - Supplementum 2. Mediaevalia Archaeologica Bohemica 1993, 60-85. Praha.

- 1999: Bronzové raně středověké nákončí z Češova, okr. Jičín - Frühmittelalterliche Bronzeriemenzunge aus Češov, Bez. Jičín, AR LI, 614-630.

- 2000: Slovanské výšinné sídliště z Třebovle, okr. Kolín. K problému napodobování cizích předloh v keramice - Die slawische Höhensiedlung in Třebovle, Bez. Kolín. Zur Nachahmung fremder Vorlagen in der Keramik, AR LII, 647-664.

- 2003: Mikulčice, pohřebiště u VI. kostela. Pokus o chronologické a sociální zhodnocení. In: Profantová, N.-Kavánová, B., Mikulčice - pohřebiště u 6. a 12. kostela. Spisy ARÚ AV ČR v Brně 22 (Kouřil, P., ed.), 7-209. Brno.

- 2011: Karolinské importy a jejich napodobování v Čechách, případně na Moravě (konec 8.-10. stol.). In: Karolínská doba a Slovensko. Sborník SNM - Archeológia supplementum 4 (Turčian, V., ed.), 71-104. Bratislava.

- 2012: Nové kovové předměty z hradiště Češov a jeho okolí - New recovered metal objects from the Hillfort of Češov and its surroundings, ASČ 16, 315-320.

- 2013: Gräber mit Sporen aus Böhmen. In: Soziale Gruppen und Gesellschaftsstrukturen im westslawischen Raum. BUFM 70 (Biermann, F.-Kersting, T.-Klammt, A., edd.), 57-76. Langenweißbach.

- 2014: Mocenské elity v Čechách 9.-10. století. Katalog. In: Velká Morava a počátky křest’anství (Kouřil, P., ed.), 56-63. Brno.

- 2015: The horse harness, spurs and stirrups in Bohemia in $8^{\text {th }}$ and $9^{\text {th }}$ century. In: Warriors, weapons, and harness from the $5^{\text {th }}-10^{\text {th }}$ centuries in the Carpathian Basin. Ethnic and cultural interferences in the 1st Millenium B.C. to the 1st Millenium A.D. Vol. XXII (Cosma, C., ed.), 281-297. Cluj-Napoca.

- v tisku: Neue Waffen- und Reitausrüstungfunde aus Mittel- und Ostböhmen. In: Bewaffnung und Reiterausrüstung des 8. bis 10. Jahrhunderts in Mitteleuropa. ITM 9 (Kouřil, P.- Poláček, L., edd.). Brno.

- v tisku a: Die Zerstörung der ersten frühmittelalterlichen Höhensiedlungen im Zusammenhang mit der Transformation an der Wende des 8. und 9. Jahrhunderts. In: BUFM 71 (Biermann, F.-Klammt, A., edd.).

PROFANTOVÁ, N.-STOLZ, D., 2006: Kovové nálezy z hradiště v Tismicích a pokus o interpretaci významu hradiště - Metal finds from the enclosure at Tismice, and attempt at interpreting the importance of the hillfort in the Early Middle Ages, ASČ 10, 793-838.

PROFANTOVÁ, N.-ŠPAČEK, J., 2003: Př́íspěvek k poznání raně středověkého osídlení v Toušeni (Lázně Toušeň), okr. Praha-východ - Der Beitrag zur Erkenntnis der frühmittelterlichen Besiedlung in Toušeň, Bez. Prag-Ost, ASČ 7, 509-529.

PROFANTOVÁ, N.-WALDHAUSER, J., 2007: Nález kování z doby avarské na hradišti Poráň (k.ú. Vesec, okr. Jičín) - An Avar Period Fitting from the Poráň enclosure (Vesec cadastre, Jičín distr.), ASČ 11, $527-530$.

ROBAK, Z., 2014: Studia nad okuciami rzemieni w typie karolińskim. VIII-X wiek. Nitra.

SCHULZE-DÖRRLAMM, M., 2009: Zeugnisse der Selbstdarstellung von weltlichen und geistlichen Eliten der Karolingerzeit (751-911). Bewertungsgrundlagen für isolierte Sachgütter aus dem Reichsgebiet Kaiser Karls des Grossen. In: Aufstieg und Untergang Zwischenbilanz des Forschungsschwerpunktes „Studien zu Genese und Struktur von Eliten in vor- und frühgeschichtlichen Gesellschaften“ (Egg, M.-Quast, D., edd.), 153-216. Mainz.

SCHWARZ, K., 1984: Frühmittelalterlicher Landesausbau im östlichen Franken zwischen Steigerwald, Frankenwald und Oberpfälzer Wald. Mainz.

SLÁMA, J., 1977: Mittelböhmen im frühen Mittelalter I. Katalog der Grabfunde. Praehistorica V. Praha. STEIN, F., 1967: Adelsgräber des achten Jahrhunderts in Deutschland I. Berlin. 
ŠTOLBA, M.-RYPKA, L., 2014: Soubor ostruh z Českého středohoří, ASČ 18, 363-377.

THEUNE, C., 1999: Frühmittelalterliche Grabfunde im Hegau. Bonn.

TUREK, J., 2001: Tišice, okr. Mělník, Výzkumy v Čechách 1999, 312-313.

ULRYCHOVÁ, E., 2008: Osídlení Jičínska ve střední době hradištní, ASČ 12, 671-692.

VIDEMAN, J.-PROFANTOVÁ, N., 2014: An der Ostgrenze des Frankenreiches. Ein Hortfund von Denaren

von Ludwig dem Heiligen bei Jedomělice (Bez. Kladno), Quaestiones Medii Aevi Novae 19, 367-389.

VÍCH, D., 2011: Archeologické nálezy z jedné privátní sbírky, ASČ 15, 999-1015.

WACHOWSKI, K., 1986/1987: Merowingische und karolingische Sporen auf dem Kontinent, Zeitschrift für Archäologie des Mittelalters 14/15, 49-79.

- 1991: Oddziaływania zachodnie na wytwórczość ostróg haczykowatych u Słowian, Przegląd archeologiczny 38, 85-107.

WALTER, S., 2008: Das frühmittelalterliche Gräberfeld von Mengen (Kr. Breisgau-Hochschwarzwald). Materialhefte zur Archäologie in Baden-Württemberg 82. Stuttgart.

WAND, N., 1999: V:14. Hakensporn. In: 799. Kunst und Kultur der Karolingerzeit. Karl der Grosse und Papst Leo III. in Paderborn, B.1 (Stiegemann, Ch.-Wemhoff, M., edd.), 279. Mainz.

ŻAK, J.-MAĆKOWIAK-KOTKOWSKA, L., 1988: Studia nad uzbrojeniem środkowoeuropejskim VI-X wieku. Zachodniobałtyjskije i słowiańskije ostrogi o zaczepach haczykowato zagiętych do wnętrza. Poznań.

\section{Zusammenfassung}

\section{Sporen als Belege für die Präsenz von Eliten im 8. und 9. Jahrhundert in Böhmen}

Sporen zählen zu den wichtigen Funden mit einer relativen chronologischen Sensibilität und liefern eine soziale Aussage über die Präsenz von lokalen, in selteneren Fällen auch fremden Kavallerien an verschiedenen, für gewöhnlich strategisch günstig gelegenen Orten. Ihre Konzentrationen (Dolánky-Rubín, Tismice, Toušeň) weisen auf Burgwälle von überregionaler Bedeutung, ggf. auf die Überreste irgendeines Kriegsereignisses hin (falls weitere Belege für eines solche Situation vorliegen). Der vorliegende Beitrag präsentiert neue Erkenntnisse über fünf Bronzesporen (auch über weitere Fragmente) sowie über weitere eiserne Haken- und Ösensporen aus Böhmen, d.h. über die ältesten frühmittelalterlichen Sporentypen. Dadurch vergrößerte sich die Zahl der Fundstellen mit Bronzesporenfunden auf sieben, die Gesamtzahl der Fundstellen mit Hakensporen auf 23 bzw. 24 und hat sich damit gegenüber dem Jahr 1994 (Abb. 9) fast verdoppelt. Davon handelt es sich lediglich in zwei Fällen um in Siedlungen gemachte Funde (z.B.Tišice), die übrigen stammen von Burgwällen (Dolánky, Tismice, Kováry-Budeč, Tismice, Toušeň) und Höhenfundstellen, die bisweilen nicht näher datierbar sind (Mořinka, Sekeřice). Die Sporen gehören durchweg in das 8. Jahrhundert bzw. an den Anfang des 9. Jahrhunderts (Sv. Jan pod Skalou - dort auch 1. Hälfte 9. Jahrhundert), wenngleich verwertbare Fundumstände zumeist fehlen oder nicht veröffentlicht wurden (Tišice). Einige der Funde zählen eindeutig zu Verlustexemplaren (Mukov, Spyšova, Štěpánov, Senohraby, Chlum u Hradce Králové, Skorkov), sie weisen meistens auf den Verlauf eines Verkehrsweges, ggf. auf einen konkreten, strategisch bedeutenderen Ort hin (Sv. Jan pod Skalou). In der Arbeit legen wir ein erweitertes typologisches Schema der tschechischen Funde vor (Abb. 11), da die neuen Funde bisher unbekannte Typen oder Varianten repräsentieren (Sporn mit kombiniertem bandförmigen und stabförmigen Bügel, mit nach außen gebogenen Ösen u.ä. - eventuell kann es sich dabei um Westimporte handeln). Ferner präsentieren wir eine Reihe neu festgestellter technologischer Details (Stacheleinsatz, Oberflächenverzinnung, geschliffene Haken - Abb. 3b, nachträgliches Anlöten des Hakens bei dem Sporn aus Mukov, reparaturmäßige Anbringung eines Hakens aus vergoldetem Blech - Abb. 3c, verschiedene Stachelverzierungstypen u.ä.). In der neuen Kollektion überwiegen Sporen mit eingesetztem Stachel (Technotyp IIa, z.B. Mořinka, Sekeřice, Senohraby, Sv. Jan pod Skalou), sodass auch das Verhältnis zu den hergestellten Sporen insgesamt ausgeglichen ist. Gleichzeitig kamen auch komplizierter profilierte Stacheln vor (Abb. 4:6, 8:6), die ihnen nahestehende Parallelen in Schlesien haben. 
Unter den böhmischen Funden befinden sich auch Luxusimporte, vor allem aus dem Westen - ein vergoldeter, reichverzierter Bronzesporn aus Skorkov mit ursprünglichem Eisendorn und Haken bzw. Ösen (Abb. 12), ein durch Granulierung verzierter und vergoldeter Sporn aus Kolín mit Platten oder ein graziler, teilweise verzinnter Sporn mit zwei von granulierten Kränzen umwickelten Nieten aus Křinec (Abb. 12) und ein wahrscheinlich ebenfalls teilweise verzinnter Sporn vom Typ I.1.c aus Sv. Jan pod Skalou.

Einige geläufigere Bronzeexemplare der Hakensporen könnten in Mähren hergestellt worden sein (Sadská, Mukov, Spyšova). Wie die ältesten, hauptsächtlich aus dem zweiten Drittel stammenden Grabfunde von Sporen mit Platten und senkrechten Nietreihen zeigen (Kolín, Kouřim, H 55 und 120, Nymburk-Zálabí, Oparno Einzelfund, Abb. 14), wurden sie direkt zum Statussymbol eines Reiters, sodass man in Erwägung ziehen kann, dass sie diese Funktion in der zweiten Hälfte des 8. sowie zu Beginn des 9. Jahrhunderts bereits erfüllt hatten. Hinsichtlich ihrer sozialen Aussage sind Sporen aus Kindergräbern die bedeutendsten. Man kennt sie nur aus dem letzten Drittel des 9. und aus der ersten Hälfte des 10. Jahrhunderts von den Fundstellen im Prager Lumbe-Garten, in der Prager Straße M. Horáková und in Kouřim (3 Fälle - Gräber 43, $63 \mathrm{~b}$ und $79 \mathrm{im}$ zentralen Teil des Gräberfeldes). Dabei handelt es sich um Gräberfelder, die zu den wichtigsten Zentren gezählt haben. Die Sporen symbolisieren den Erbstatus, den ein vorzeitig verstorbenes Kind von zur Elite zählenden Eltern in der realen Welt nicht mehr erlangen konnten.

In dem Exkurs werden vier unvollständige Hakensporen aus Brno- Líšeň veröffentlicht, ein Fragment gehört zu einem Bronzeexemplar - dem ersten an der Fundstelle, bei dem anderen wurde anhand einer RFA-Analyse (siehe Tab. 1) erstmals in diesem Umkreis eine Verzinnung nachgewiesen. Es gehört ebenfalls in das 8. Jahrhundert. Brno-Líšeň kommt hinsichtlich der Anzahl der gefundenen Hakensporen (9-10 Exemplare) direkt hinter Mikulčice und wohl auch nach dem Burgwall Víno in Schlesien.

PhDr. Nad’a Profantová, Ph.D., Archeologický ústav AV ČR, Praha, v. v. i., Letenská 4, 11801 Praha, Česká republika,profantova@arup.cas.cz 